\title{
The first consistent inventory of rock glaciers and their hydrological catchments of the Austrian Alps
}

\author{
Thomas Wagner', Roswitha Pleschberger ${ }^{1,6}$, Simon Kainz, Markus Ribis², Andreas Kellerer-Pirklbauer ${ }^{3}$, Karl Krainer, \\ Rudolf Philippitsch ${ }^{5}$, Gerfried Winkler ${ }^{1 *}$ \\ 1) Institute of Earth Sciences, NAWI Graz Geocenter, University of Graz, Heinrichstrasse 26, 8010 Graz, Austria; thomas.wagner@uni-graz.at; gerfried. \\ winkler@uni-graz.at; simon.kainz@edu.uni-graz.at \\ ${ }^{2)}$ geo.zt gmbh - poscher beratende geologen, Saline 17,6060 Hall in Tirol, Austria; markus.ribis@geo-zt.at \\ 3) Department of Geography and Regional Science, Working Group on Alpine Landscape Dynamics (ALADYN), University of Graz, Heinrichstrasse 36, \\ 8010 Graz, Austria; andreas.kellerer@uni-graz.at \\ 4) Institute of Geology, University of Innsbruck, Innrain 52, 6020 Innsbruck, Austria; karl.krainer@uibk.ac.at \\ 5) now retired; former Ministry of Sustainability and Tourism, Stubenring 1, 1010 Vienna, Austria; rudolf.philippitsch@hotmail.com \\ ${ }^{6)}$ now at Geotechnik Team GmbH, Technikerstrasse 3, 6020 Innsbruck, Austria; rp@geotechnik-team.at \\ *) Corresponding author: gerfried.winkler@uni-graz.at; phone +43 316380 5585; fax +43 316380 9870; ORCID ID https://orcid.org/0000-0003-1742-1242
}

KEYWORDS rock glacier inventory; periglacial landform; permafrost; hydrological catchment; Austrian Alps

\begin{abstract}
A first consistent and homogenized polygon-based inventory of rock glaciers of the Austrian Alps is presented. Compiling previous inventories and updating them by using digital elevation models ( $1 \mathrm{~m}$ grid resolution) derived from airborne laser scanning yield a dataset of 5769 rock glaciers in a ca. $48400 \mathrm{~km}^{2}$ large area. A consistent methodological approach for assigning attributes, stored in a detailed attribute table, was developed and applied here to improve comparability and reproducibility. The majority ( $60 \%$ ) of the studied landforms is considered to be relict (no permafrost); the remaining $40 \%$ may still contain permafrost ice and are thus classified as intact. Rock glaciers range in elevation from 476 to $3312 \mathrm{~m}$ a.s.l. and cover a total area of $303 \mathrm{~km}^{2}$. The distribution of rock glaciers is mainly related to the topography of the Austrian Alps and related effects such as past glaciation history.

In addition, a comprehensive analysis of the hydrological catchment areas of all individual rock glaciers was carried out. A hydrological catchment analysis in rock glacier areas is of great interest for sustainable water management issues in alpine catchments as these landforms represent shallow aquifer systems with a relatively high storage and thus buffer capability, especially in crystalline bedrock areas. A total area of almost $1280 \mathrm{~km}^{2}$ is drained through rock glaciers.

The presented rock glacier and rock glacier catchment inventories provide an important basis for further research, particularly for a better understanding of the hydrogeology and geomorphology of alpine catchments and their potential alteration in the light of climate change, but also in terms of paleoglaciation and deglaciation in the Alpine Lateglacial to Holocene period. As such, the inventories are seen as an important base to stimulate further research.
\end{abstract}

\section{Introduction}

Rock glaciers are the most prominent periglacial landforms in high mountain areas indicating permafrost conditions during the period of formation and activity (e.g. Millar and Westfall, 2008; Boeckli et al., 2012). Tongue-shaped or lobate creeping landforms (cohesive flow) of perennially frozen debris material are termed active rock glaciers. They move slowly downslope, thereby forming generally longitudinal ridges on their upper parts and transversal ridges and furrows on their lower part (e.g. Berthling, 2011; Kellerer-Pirklbauer et al., 2012). When creeping stops due to climate warming (ice melt), a cease of debris-supply, or an advance to a less steep topography, active rock glaciers become inactive. Inactive and active rock glaciers are summarized as intact rock glaciers as both contain permafrost ice (Barsch, 1996). When permafrost ice completely thaws, rock glaciers become relict. Collapse structures and extensive vegetation cover are typical features of relict rock glaciers. But even morphologically relict-looking rock glaciers still may contain substantial volumes of permafrost ice, therefore a clear distinction between intact and relict rock glaciers based on morphology is still challenging (Sorg et al., 2015; Colucci et al., 2019; Kellerer-Pirklbauer, 2019). Depending on the genesis and elevation of the landforms (e.g. Knight et al., 2019), relict as well as intact rock glaciers are encountered in the Austrian Alps (Lieb et al., 2012).

On the one hand, intact rock glaciers pose potential natural hazards, as changes in creeping velocities (e.g. permafrost thawing due to climate warming) might trigger rock fall or debris flows (e.g. Kellerer-Pirklbauer et al., 2012; Haeberli et al., 2017; Scotti et al., 2017), 
although only few current cases are known in Austria (e.g. Kaufmann et al., 2017). On the other hand, these landforms serve as palaeo-climate indicators in the Austrian Alps and elsewhere if found in a relict (e.g. Rode and Kellerer-Pirklbauer, 2012; Moran et al., 2016) or even active (Kellerer-Pirklbauer, 2008) stage. Probably more important for the human society as well as for alpine ecology, rock glaciers represent shallow groundwater bodies with relevant storage or buffer capacities (Wagner et al., 2016; Winkler et al., 2016, 2018a; Pauritsch et al., 2017; Harrington et al., 2018). These landforms may temporarily store and further release water in a delayed way compared to catchments without such landforms. This is of interest for the drainage pattern of alpine catchments with an abundance of rock glaciers and their potential change over time in the light of climate change (Rogger et al., 2017). Recent findings also indicate distinct water quality issues such as heavy metal contaminations observed at rock glacier springs that are not related to any mining activities (Krainer et al., 2015; Thies et al., 2017; Ilyashuk et al., 2018).

To contribute to these research questions, rock glacier inventories have been compiled in various parts of the earth with different mapping sources available; e.g. orthophotos, Google Earth imagery or ideally / recently using airborne laser scans. Jones et al. $(2018,2019)$ provide a recent worldwide overview of mountain rock glaciers and their global role in the water cycle.

Within the DaFNE-research project RGHeavyMetal (Nr. 101093; Wagner et al., 2019a) an inventory of rock glaciers of Austria was compiled based on available high-resolution digital elevation models (airborne laser scanning (ALS) data of $1 \mathrm{~m}$ horizontal resolution) and earlier inventories (see below). The new inventory is an important basis relevant for the implementation of the EU water framework directive 2000/60/EG, the water act 1959 "i.d.g.F." (meaning "in the current version") and the national water management plan for the description and characterization of these high alpine landforms acting as special forms of porous aquifers, so that water management is optimized in an economical as well as ecological way in these highly sensitive catchments. For this purpose the polygon-based rock glacier inventories of i) central and eastern Austria (Kellerer-Pirklbauer et al., 2012, 2016; Lieb et al., 2012), ii) of the Tyrolean Alps (Krainer and Ribis, 2012) and iii) of Vorarlberg (Stocker and Krainer, 2011; Stocker, 2012a,b) have been re-evaluated, adjusted and extended. The existence of low-lying rock glaciers is conceivable if judged from the glacial and periglacial landscape evolution in Austria during the Pleniglacial and Lateglacial period. However, the main focus was on alpine areas with potential rock glacier occurrence in the federal states of Vorarlberg, Tyrol, Salzburg, Styria and Carinthia (in total $48400 \mathrm{~km}^{2}$ ) which were investigated in detail. For these areas high resolution digital elevation models were analysed.

As the compilation of existing rock glacier inventories needs some sort of homogenization of various attributes related to rock glaciers (e.g. length and aspect), the presented inventory aimed at defining attributes in a consistent and reproducible way. Thus, various automatic / computerbased steps were performed and previous attribution was dismissed. The problem of identifying and delineating rock glaciers (particularly relict rock glaciers at low elevation) is a subjective task that needs to be acknowledged (e.g. Schmid et al., 2015; Anderson et al., 2018). In our study, verification of mapping results happened by exchange between the individual mapping persons thereby reducing ambiguities. A clear verification of the landforms, however, will ask for additional time and financial commitment and even then, uncertainties might remain (Harrison et al., 2008; Jarman et al., 2013).

The aim of this paper is to (i) present the consistent methods that were used to generate the inventories themselves and the generated attribute database and (ii) to present some summary statistics of these first consistent inventories of the Austrian Alps.

\section{Study area}

The investigated area comprises the area of the federal states of Vorarlberg, Tyrol, Salzburg, Styria and Carinthia (Figure 1). This area covers all the regions in which previous inventories (Stocker and Krainer, 2011; Kellerer-Pirklbauer et al., 2012, 2016; Krainer and Ribis, 2012; Lieb et al., 2012; Stocker, 2012a,b) have identified rock glaciers. This excludes potential, densely-vegetation covered landforms in e.g. the Bohemian Massif or below the timber line in the Rax area of the easternmost part of the Northern Calcareous Alps. However this will concern only a very limited number of questionable periglacial debris accumulations (van Husen, 1996; discussed in Kellerer-Pirklbauer et al., 2012). A screening of suspected landforms across the borders of the federal states of Styria and Salzburg in the two federal states of Upper and Lower Austria was done based on overlapping high-resolution digital elevation models as well as by using freely available hillshades and orthophotos (10 m spatial resolution). However, no rock glaciers were identified there due to data limitation (for a single suspected landform previously mapped, see Lieb et al., 2012 (RG_CODE = $\operatorname{tr} 1))$. Figure 1 also depicts the physiographic sections of the larger provinces of the Eastern Alps separating the study area into the Northern Calcareous Alps, the Central Eastern Alps and the Southern Calcareous Alps.

The study area shows a variable topography with a general trend of decreasing elevations towards the east and large areas at high altitudes in the Central Alps with a maximum elevation of $3798 \mathrm{~m}$ a.s.l. at Großglockner (Figure 1). The Austrian Alps, as part of the European Eastern Alps, are built up by variable and complex geology (e.g. Schmid et al., 2004). A differentiation between regions of predominantly carbonate rocks (e.g. Northern Calcareous Alps), metamorphic (crystalline) rocks (basement, etc.) and less resistant shales and platy (thinly bedded) limestone is relevant for rock glacier development, concerning the availability of coarse debris (e.g. Ikeda and 


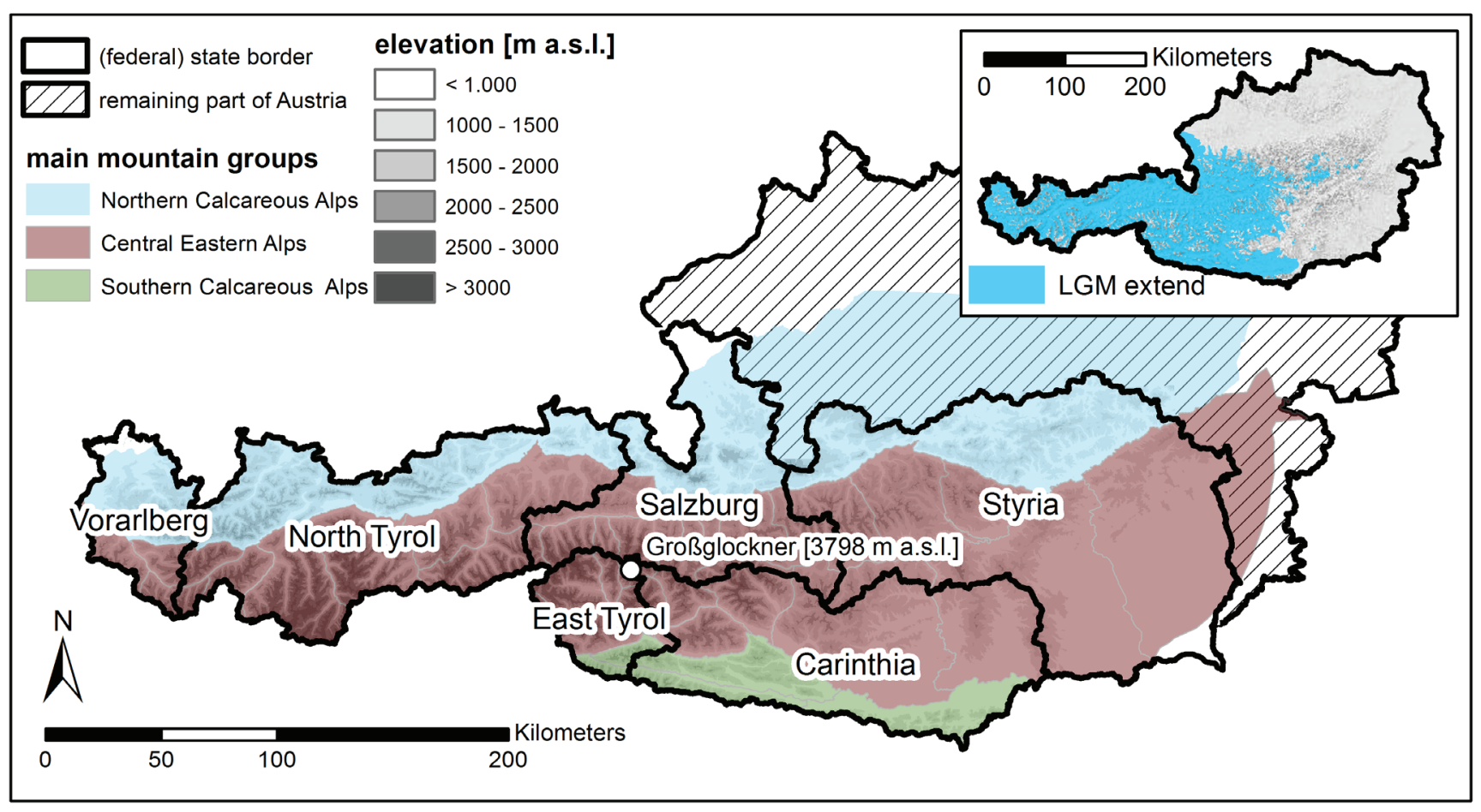

Figure 1: The study area within Austria includes the federal states of Vorarlberg, Tyrol (with the two parts of East and North Tyrol), Salzburg, Styria and Carinthia (borders shown as black lines; the national border of Austria is shown for orientation) and the subdivision into the three main mountain groups. The topography of the study area is depicted by elevation zones with intervals of $500 \mathrm{~m}$ based on ALS data provided by the federal states and highlights the differences between individual federal states (e.g. Tyrol versus Styria). The not investigated remaining part of Austria is shown with a simple hatch as no $1 \mathrm{~m}$ ALS data were provided there. The inset depicts the last glacial maximum (LGM) extend within Austria based on Ehlers et al. (2011).

Matsuoka, 2006). The climate of the Eastern Alps is complex due to influences from the Atlantic, the Mediterranean and the Pannonian (higher continentality) realms (e.g. Beniston, 2005). Also the Pleistocene glaciation history of Austria is diverse. The easternmost limit of the interconnected last glacial maximum (LGM)-glacier system in Austria is at about longitude 15 (Figure 1 inset; Ehlers et al., 2011; van Husen, 2011). Geomorphologically, these various differences are reflected in the landscape and also influence rock glacier genesis. However, the aim of this work is describing the rock glacier inventory and does not try to solve the evolution history of individual rock glaciers, which is beyond the scope of this work.

\section{Methods and database}

The most recent polygon-based rock glacier inventories that were available (Stocker and Krainer, 2011; Krainer and Ribis, 2012; Kellerer-Pirklbauer et al., 2012, 2016, Lieb et al, 2012) were compiled, re-evaluated and updated accordingly. The delineation of the landforms or a check of previously mapped landforms were done primarily using airborne laser scanning (ALS) data with a $1 \mathrm{~m}$ horizontal resolution and its derivatives (slope maps, hillshades with different illumination azimuths) as important advances to previous inventories. An exception is the inventory of Krainer and Ribis (2012), for which ALS data of 1 m horizontal resolution was already available. No lower limit of e.g. $1000 \mathrm{~m}$ a.s.l. (as by Kellerer-Pirklbauer et al., 2012) was used for the mapping, as lower lying rock glaciers might be present and may not have yet been discovered due to extensive forest cover and limited use of orthophotos there (Kellerer-Pirklbauer et al., 2016). In addition, orthophotos, geological maps and literature were included to complement the analysis. Moreover, field verification was done in several regions by the authors (in the order of 100 landforms).

\subsection{Rock glacier inventory}

Rock glaciers which are considered to be discrete debris accumulations with a high chance of representing an (former) ice-debris landform sensu Jones et al. (2017) were delineated manually by the authors using ArcGIS (Version 10.4). During the mapping procedure, the mapping result of one person was checked by another. Independent mapping and subsequent comparison would be ideal (cf. Schmid et al., 2015; Bradinoni et al., 2019), however, was beyond the financial and time constraints here. Morphological evidence such as steep front and lateral slopes, ridges and furrows, collapse structures, flow structures and distinct changes of the slope in the rooting zone were used for the landform delineation (cf. Schmid et al., 2015). Furthermore, protalus ramparts, defined as initial talus-derived rock glaciers considered as an "embryonic" stage of rock glacier development (Ballantyne and Kirkbridge, 1986; Scapozza, 2015), were included in the inventory. As transitions between large solifluction lobes and small rock glaciers are blurred, no minimum dimensions were defined here (as done in Krainer and Ribis, 2012). The authors are well aware of the problem related 
to the delineation of rock glaciers and protalus ramparts versus debris-covered glaciers and pronival ramparts, respectively (e.g. Jarman et al., 2013; Hedding, 2016). The persons having done the mapping are indicated in the list of attributes of the inventory.

For each polygon of the rock glacier inventory a total of 34 attributes were assigned. The attributes refer to coding, name, reference to previous inventories, spatial position, geometry, activity status, shape of the rock glaciers and information about springs emerging at the front of rock glaciers. Table 1 lists the attributes and how they were allocated. All attributes related to topographic information that can be extracted by intersections of the landform polygon with the digital elevation model were extracted thereof (minimum, mean and maximum elevation, mean slope, etc.). All attributes that can be extracted by a spatial join with other data sets were extracted thereof (e.g. mountain ranges; defined according to Grassler (1984) and related to the classification of the Eastern Alps provided by the Austrian Alpine Club).

Focus has been laid in the attribution procedure on reproducibility of the actual attributes; e.g. length and width of a landform were measured by digitizing polylines with a total of five vertices (Figure 2). This step is necessary, because landforms might be shaped in a way that a straight line representing length or width would be inaccurate. Moreover, this allows re-evaluating these attributes. The aspect of rock glaciers was assigned automatically by using the directional mean of the polyline identifying the maximum length of the landform (Figure 2). The shape of rock glaciers (tongue-shaped or lobate) was computed based on the ratio of length to width, thereby improving consistency (Figure 2). On the one hand, a maximum width was measured (polyline with five vertices), on the other hand a mean width was computed based on the area of the rock glacier divided by its maximum length. If the maximum length to maximum / mean width ratio was close to one (0.9-1.1), both ratios (maxLen/maxWidth; maxLen/meanWidth) were used. So, 470 out of 5769 landforms have been checked manually for tongue-shaped (TS) vs. lobate (LS). In addition, a manual check was needed to differentiate complex landforms (CX).

This is regarded as an important approach when compiling (and extending) inventories of different origin.

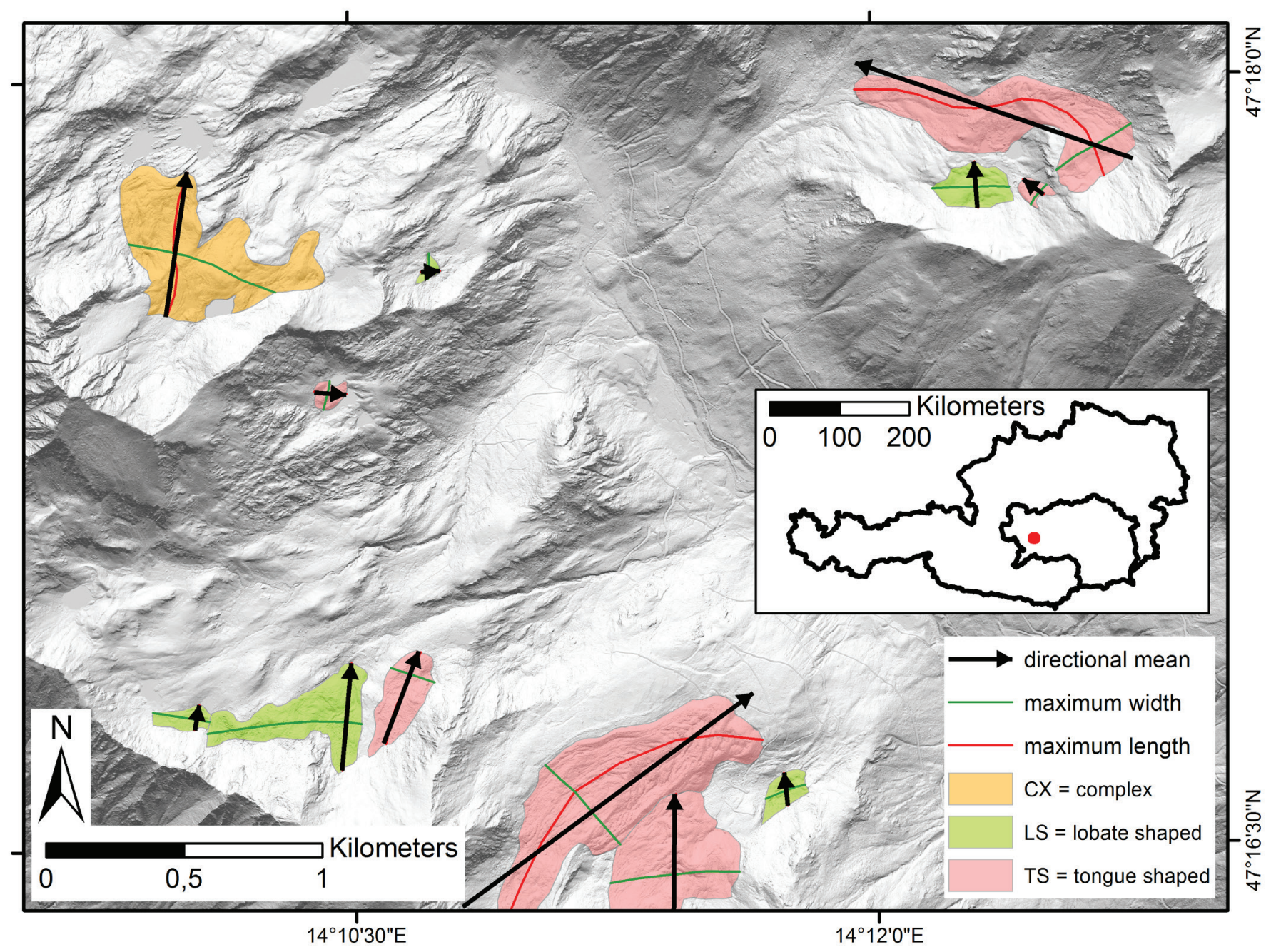

Figure 2: Assignment of rock glacier attributes. Maximum length and width of some exemplary rock glaciers in the Rottenmanner and Wölzer Tauern Range (Styria) are based on polylines with five vertices. Aspect of the landform was computed as the average orientation of the maximum length polyline. Shape of the landform was computed based on the ratio of maximum length to maximum and/or mean width (LS=lobate shaped, TS=tongue shaped) and was manually checked for complex landforms (CX) or when length to width ratios were close to one. 


\begin{tabular}{|c|c|c|c|c|c|}
\hline$\#$ & parameter & brief description & $\begin{array}{l}\text { categories / units } \\
\text { / example }\end{array}$ & format & $\begin{array}{l}\text { assignment } \\
\text { procedure }\end{array}$ \\
\hline 1 & intNr & internal serial number of the rock glacier (or protalus rampart) & e.g. 37801 & long integer & calc \\
\hline 2 & pers & name of the person who did the mapping & $\begin{array}{l}\text { KPA }=\text { Andreas Kellerer-Pirklbauer; KrK = Karl } \\
\text { Krainer; RiM = Markus Ribis; PIR = Roswitha } \\
\text { Pleschberger; WaT =Thomas Wagner }\end{array}$ & text (10) & man \\
\hline 3 & LfType & $\begin{array}{l}\text { landform type; differentiation between rock glaciers and pro- } \\
\text { talus ramparts; transitional forms are marked with } a_{n} \text { ?" }\end{array}$ & $\begin{array}{l}\mathrm{rg}=\text { rock glacier; } \mathrm{ptr}=\text { protalus rampart/embryo- } \\
\text { nal rock glacier; transitional form rg?, ptr? }\end{array}$ & text (4) & man \\
\hline 5 & LfCode_old & $\begin{array}{l}\text { the landform code that has been used in previous invento- } \\
\text { ries if the deliniation has not changed too much; if a new } \\
\text { landform has been mapped: „new“ }\end{array}$ & e.g. rg1234; new & text (10) & spj \\
\hline 6 & name & $\begin{array}{l}\text { name of the landform, based on a topographic feature near- } \\
\text { by, such as a summit or a lake as used in the ÖK 1:50000 } \\
\text { maps and its location relative to it }\end{array}$ & $\begin{array}{l}\text { e.g."W Querlstein" is the name of a rock glacier } \\
\text { that is located west of the mountain "Querlstein" }\end{array}$ & text (50) & $\operatorname{man}$ \\
\hline 8 & maxWidLf & $\begin{array}{l}\text { maximum width of the landform about perpendicular to the } \\
\text { (former) creeping direction }\end{array}$ & [m]; e.g. 101 & double & man \\
\hline 9 & meanWidLf & Mean width $=$ areaLf $/$ maxLenLf & [m]; e.g. 76 & double & calc \\
\hline 10 & ratioLWLf & length/width ratio $=$ maxLenLf $/$ meanWidLf & {$[-]$} & double & calc \\
\hline 11 & xCoord & $x$-coordinate of the centroid of the polygon (easting) & [m]; e.g. 485951.2 & double & calc \\
\hline 12 & yCoord & $y$ - coordinate of the centroid of the polygon (northing) & [m]; e.g. 207072.5 & double & calc \\
\hline 13 & sys_Merid & $\begin{array}{l}\text { system and meridian; similar to the data of the airborne laser } \\
\text { scan provided by the federal states }\end{array}$ & BMN-M31; BMN-M34; GK-M31; GK-West & text (10) & spj \\
\hline 14 & asplf & $\begin{array}{l}\text { average aspect and (former) flow direction (8 different as- } \\
\text { pect classes) }\end{array}$ & e.g. NE & text (2) & calc \\
\hline 15 & asplfDeg & average aspect and (former) flow direction & {$\left[^{\circ}\right]$ (integral value) } & short integer & calc \\
\hline 16 & slopelf & $\begin{array}{l}\text { mean slope of the landform (influenced by the surface mor- } \\
\text { phology of the rock glacier) }\end{array}$ & {$\left[{ }^{\circ}\right]$} & double & calc \\
\hline 17 & minElevLf & $\begin{array}{l}\text { elevation above sea level of the lowest point (base of the } \\
\text { front slope) of the landform }\end{array}$ & [m a.s.l.]; e.g. 2134 & double & calc \\
\hline 18 & meanElevLf & $\begin{array}{l}\text { mean elevation above sea level of the landform (not neces- } \\
\text { sarily similar to the elevation of the centroid of the polygon) }\end{array}$ & [m a.s.l.]; e.g. 2222 & double & calc \\
\hline 20 & elevRangLf & elevation difference (relief) between maxElevLf and minElevLf & [m]; e.g. 167 & double & calc \\
\hline 21 & moRang & $\begin{array}{l}\text { mountain range, in which the rock glacier is located, based } \\
\text { on the AVE classification (Grassler, 1984) }\end{array}$ & e.g. Ötztaler Alpen & text (50) & spj \\
\hline 22 & GWK_Nr & $\begin{array}{l}\text { number of the groundwater body, in which the rock glacier } \\
\text { is located (NGP, 2015) }\end{array}$ & e.g. GK100185 & text (10) & spj \\
\hline 23 & GWK_Bez & $\begin{array}{l}\text { name of the groundwater body, in which the rock glacier is } \\
\text { located (NGP, 2015) }\end{array}$ & e.g. Salzburger Hohe Tauern [MUR] & text (100) & spj \\
\hline 24 & arealf & projected surface area of the landform polygon & {$\left[\mathrm{m}^{2}\right]$} & double & calc \\
\hline 25 & LfState & state of activity of the rock glacier & INT = intact (active and inactive); REL = relict & text (3) & calc \\
\hline 26 & LfMorph & $\begin{array}{l}\text { Rock glacier with one or more generations; monomorph or } \\
\text { polymorph sensu Frauenfelder and Kääb (2000) }\end{array}$ & $\begin{array}{l}\mathrm{m}=\text { monomorph; } \mathrm{p}=\text { poly-morph; for } \mathrm{ptr}=\mathrm{m} ; \\
\text { if unclear: } \mathrm{p} \text { ? }\end{array}$ & text (2) & man \\
\hline 27 & LfShape & $\begin{array}{l}\text { shape of the landform; differentiation between tongue and } \\
\text { lobate shape as well as complex forms }\end{array}$ & $\begin{array}{l}\text { TS }=\text { tongue-shaped ( length }>\text { width); } \mathrm{LS}=\text { lobate } \\
\text { (width }>\text { length); } C X=\text { complex (multiple tongues } \\
\text { or lobes or a mix thereof) }\end{array}$ & text (2) & $\mathrm{calc} / \mathrm{man}$ \\
\hline 28 & LfFormat & $\begin{array}{l}\text { information about the genesis of the landform (as much as this } \\
\text { is deducible from digital elevation models and orthophotos) }\end{array}$ & $\begin{array}{l}\text { TAL = talus-derived (ice-cemented); GLA = gla- } \\
\text { cier-derived (ice-cored); for ptr =TAL; if unclear: GLA? }\end{array}$ & text (4) & man \\
\hline 29 & LfSpring & information concerning springs at the rock glacier front & $\begin{array}{l}0=\text { no spring; } 1=\text { one spring; } 2=\text { two springs; } \\
\text { etc. } \ldots ; 99=\text { lake; },-99=\text { not known }\end{array}$ & short integer & man \\
\hline 30 & commentLf & additional comment about the landform & $\begin{array}{l}\text { e.g. spring capture at the base of the front (ref: } \\
\text { Untersweg and Schwendt, 1995) }\end{array}$ & text (100) & man \\
\hline 31 & entryData & $\begin{array}{l}\text { year in which the landform was digitized (which is not nec- } \\
\text { essarily the date in which the underlying digital elevation } \\
\text { model was generated) }\end{array}$ & e.g. 2016 & short integer & man \\
\hline 32 & mainStream & $\begin{array}{l}\text { watershed of water body in which the landform is located } \\
\text { (HZB classification) }\end{array}$ & e.g. Gurgler Ache & text (100) & spj \\
\hline 33 & H2O_DB & $\begin{array}{l}\text { code related to spring water sampling found in the } \mathrm{H}_{2} \mathrm{O} \\
\text { database (only for individual landforms) }\end{array}$ & $\begin{array}{l}\text { e.g. BLGL6_0001 relates to the spring SEQ in the } \\
\text { H2O-database }\end{array}$ & text (50) & spj \\
\hline 34 & referencLf & literature related to the landform & e.g. Krainer and Mostler (2002) & text (100) & $\operatorname{man}$ \\
\hline
\end{tabular}

Table 1: List of attributes of the rock glacier inventory. Attribute names, short descriptions, examples and data types are listed. The assignment procedure is listed in the final column: calc = calculated; spj = spatial join; man = manual entry. 
Besides a better delineation due to higher resolution ALS data, also the landform attributes are more consistent as they were whenever possible computed in a uniform way and subjectivities of individual mapping personal was reduced. This homogenization and certain standardization is seen as a step forward in a consistent methodological approach as followed here.

Another homogenization and, to a certain degree, simplification had to be introduced in the attribution of the activity status of a landform. Based on Wagner et al. (2018), a differentiation between relict (fossil) and intact (active or inactive) rock glaciers was followed here. For an objective differentiation, the regional permafrost model of Boeckli et al. (2012), which is based on permafrost indicators such as mean annual air and rock surface temperature, potential incoming solar radiation and rock glacier information to derive the model and further used independent rock glacier information from Alpine-wide data sets to evaluate the model, was used to classify rock glaciers as 'relict' or 'intact'. Rock glaciers were considered as relict when absence of permafrost is indicated by the regional permafrost model or if only the uppermost part of the entire rock glacier surface was slightly within the modeled permafrost area. In contrast, rock glaciers were classified as intact when the rock glacier body was entirely within the modeled permafrost or if at least most of the rock glacier was in the model class 'permafrost only in very favorable conditions'. However, a clear distinction between active and inactive rock glaciers is only possible if a surface displacement analysis was carried out using multitemporal rock glacier surface data, which were not available here. Even a differentiation of relict and intact rock glaciers is still challenging using only remote sensing and geomorphological evidences (e.g., vegetation cover) as was discussed recently by Colucci et al. (2019). There are important limitations of the method applied here and to really differentiate different activity statuses from another and relate these to the presence of discontinuous mountain permafrost, further intensive field work and automatic monitoring of permafrost-related parameters (e.g. ground temperature, geophysics) is needed. Ground surface temperatures, spring temperatures and geophysical data will provide information on the presence or absence of ice within the rock glaciers (Colucci et al., 2019; Kellerer-Pirklbauer, 2019; Wagner et al., 2019b). However, the necessary field work for every single rock glacier is beyond the scope of this work. The chosen approach is a consistent one, thereby limiting subjectivity of visual differentiation from different persons who mapped the landforms.

The landform genesis was estimated by differentiating between talus-derived (ice-cemented) and glacier-derived (ice-cored) rock glaciers. Rock glacier genesis is however difficult to assign, particularly for relict rock glaciers based on remote sensing data. Defining the activity status as well as the genesis of rock glaciers will demand additional (field) work and was beyond the scope of the inventorying procedure.

\subsection{Rock glacier catchment inventory}

The land surface area that is drained through rock glaciers is relevant for various water management issues (e.g. Wagner et al., 2016). The first rock glacier catchment inventory was designed in a consistent reproducible way for the Austrian Alps. For the catchment delineation the following procedure was developed and applied consistently for the entire rock glacier inventory. Catchments were computed using standard ArcGIS hydrology tools (Version 10.4). All grid cells of $1 \mathrm{~m}$ horizontal resolution flowing towards the rock glaciers were considered to be contributing to the catchment area (Winkler et al., 2018b). This approach assumes that the orographic catchment equals the hydrological one. Although this is a simplification, it is a suitable first approach for crystalline areas which are only influenced to a very limited extent by marble. In karstified areas, an uncertainty must be taken into account. A verification (or falsification) will ask for catchment delineation via tracer tests and is beyond the scope of this work (e.g. Lauber et al., 2014). A general statement is not possible as the catchment area may vary from place to place, depending on the regional geology and even on the hydrometeorological conditions (Wagner et al., 2013; Zebre and Stepisnik, 2015). The catchment delineation was checked manually for outliers, as e.g. forest roads may create artificial flow paths. This information is documented in the list of attributes ("delinlssue"), and further field verification will be necessary to clarify these issues. An overview of all 13 assigned attributes of the catchment inventory is presented in Table 2.

Most of the attributes are self-explanatory (e.g. maxEleCat = maximum elevation within the catchment), whereas two need further discussion here. In the catchment inventory, an "areaCat" and an "areaCatInd" are designated. This is necessary, as each landform has its individual catchment area ("areaCatInd"), i.e. the land surface that is drained through the rock glacier. However, when computing the contributing surface area for a certain region (e.g. a distinct valley or a federal state), summing up the individual catchment areas would lead to an overestimation, because catchment areas may overlap. Figure 3 depicts an example of rock glacier 6RG535 (dark orange polygon) and its individual catchment ("areaCatlnd") as light orange polygon. There are two more rock glaciers sharing (parts of) the same catchment. Thus, the non-overlapping "areaCat" of 6RG535 is reduced accordingly (orange crosshatch). The rock glacier 6RG534 (dark blue polygon) is located on a saddle / drainage divide and drained partly through the 6RG533 and 6RG535 rock glaciers. However, the northeastern part of its catchment drains into that part of the rock glacier that is located on the other side of the saddle. As such, the light orange polygon of the 6RG535 individual catchment does not fully include the light blue polygon of the individual catchment of the 6RG534 rock glacier. For this reason, overlapping catchment areas were only accounted for once; i.e. if the area in the attribute "areaCat" is smaller than the "areaCatInd", an overlap with another catchment exists. 


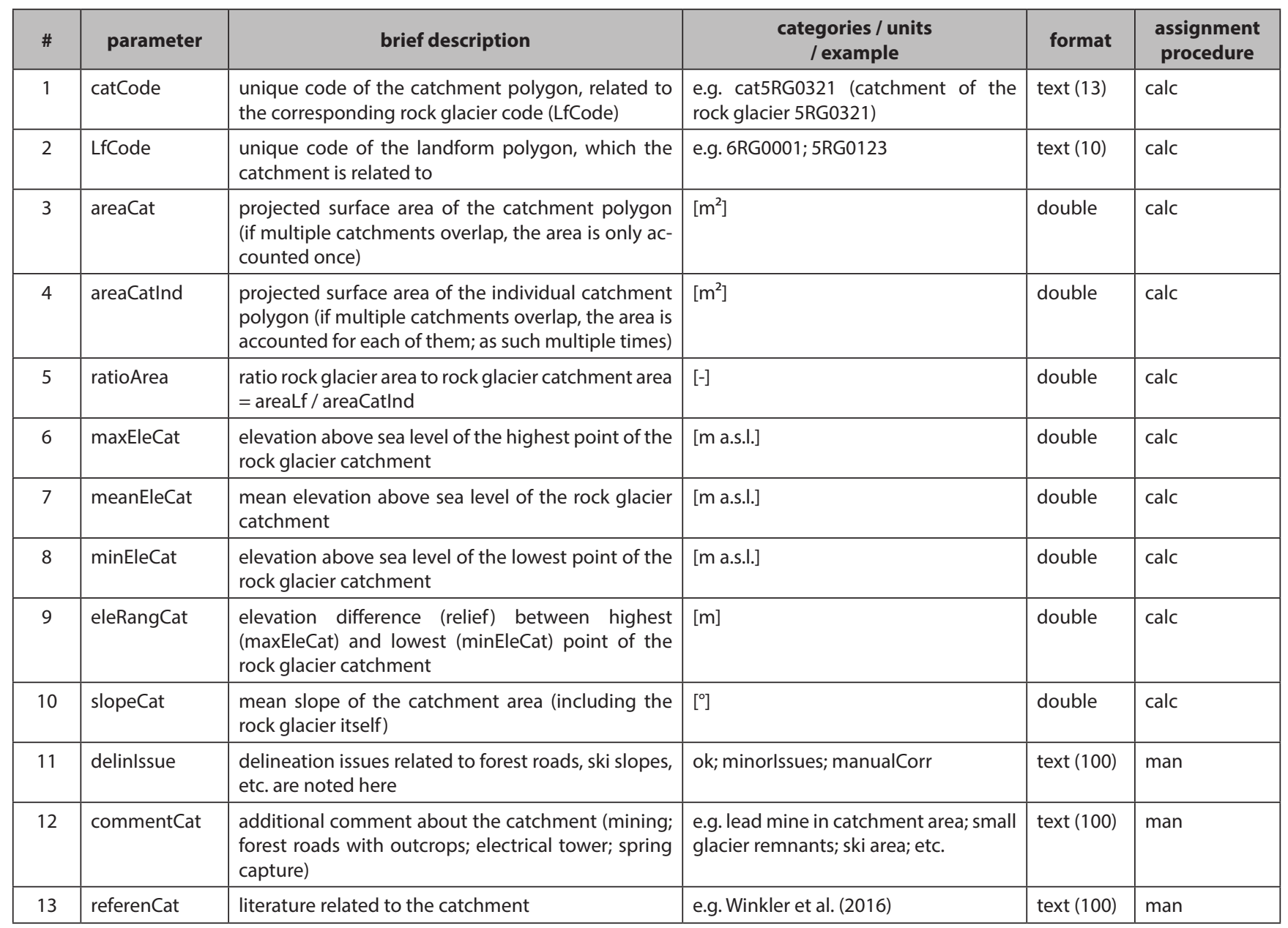

Table 2: List of attributes of the rock glacier catchment inventory. Attribute names, short descriptions, examples and data types are noted.

In the results section the minimum elevation of the front slope above sea level (minElevLf) is used when analyzing the elevation distributions of the rock glacier inventory, as this elevation is relevant when considering potential spring water outflows. In contrast, for the rock glacier catchment data, the mean elevation of the catchment is used (meanEleCat), as the mean elevation is relevant for hydrometeorological considerations and input data. For the rock glacier and the rock glacier catchment polygons, minimum, mean and maximum elevations are available in the inventories. There are very few landforms and particularly catchments that extend across federal state boundaries, in such cases rock glaciers are allocated to the one federal state with higher landform share and catchments to the federal state the rock glaciers are situated in.

\section{Results}

\subsection{Rock glacier inventory}

A total of 5769 rock glaciers were identified in the Austrian Alps. This increases the amount of previously mapped rock glaciers in Austria by 1219, although in the new inventory some previously mapped rock glaciers had to be dismissed as no clear morphological indication for past permafrost creep of these landforms could be verified using the ALS data (e.g. Kellerer-Pirklbauer et al., 2016).

The distribution of all rock glaciers as centroids, colorcoded according to their minimum elevations (minElevLf) is shown in Figure 4. The number of rock glaciers, areal coverage of rock glaciers and the elevation distribution of the landforms are presented in Table 3 for the mapped part of the Austrian Alps and for the federal states (with an additional separation of Tyrol into North and East Tyrol) individually. This subdivision into federal states was chosen, as in Austria water management is done on federal states level.

The largest number of all rock glaciers is recorded in Tyrol (3148), 303 were delineated in Vorarlberg. The rock glaciers cover an area of $303 \mathrm{~km}^{2}$; the largest area covered by rock glaciers was measured in Tyrol $\left(167 \mathrm{~km}^{2}\right)$. The median elevation of the base of the front slope of all the rock glaciers (minElevLf) is $2276 \mathrm{~m}$ a.s.l., although this varies noticeably when considering individual federal states (Figure 5a). In Styria a median elevation of the rock glacier front of $1854 \mathrm{~m}$ a.s.l. is encountered. The other extreme is Tyrol, where median elevations are 2457 and 2428 m a.s.l. for East and North Tyrol, respectively. Figure $5 \mathrm{~b}$ and $5 \mathrm{c}$ show the elevation distribution of intact and relict rock glaciers in North Tyrol and Styria in detail. 


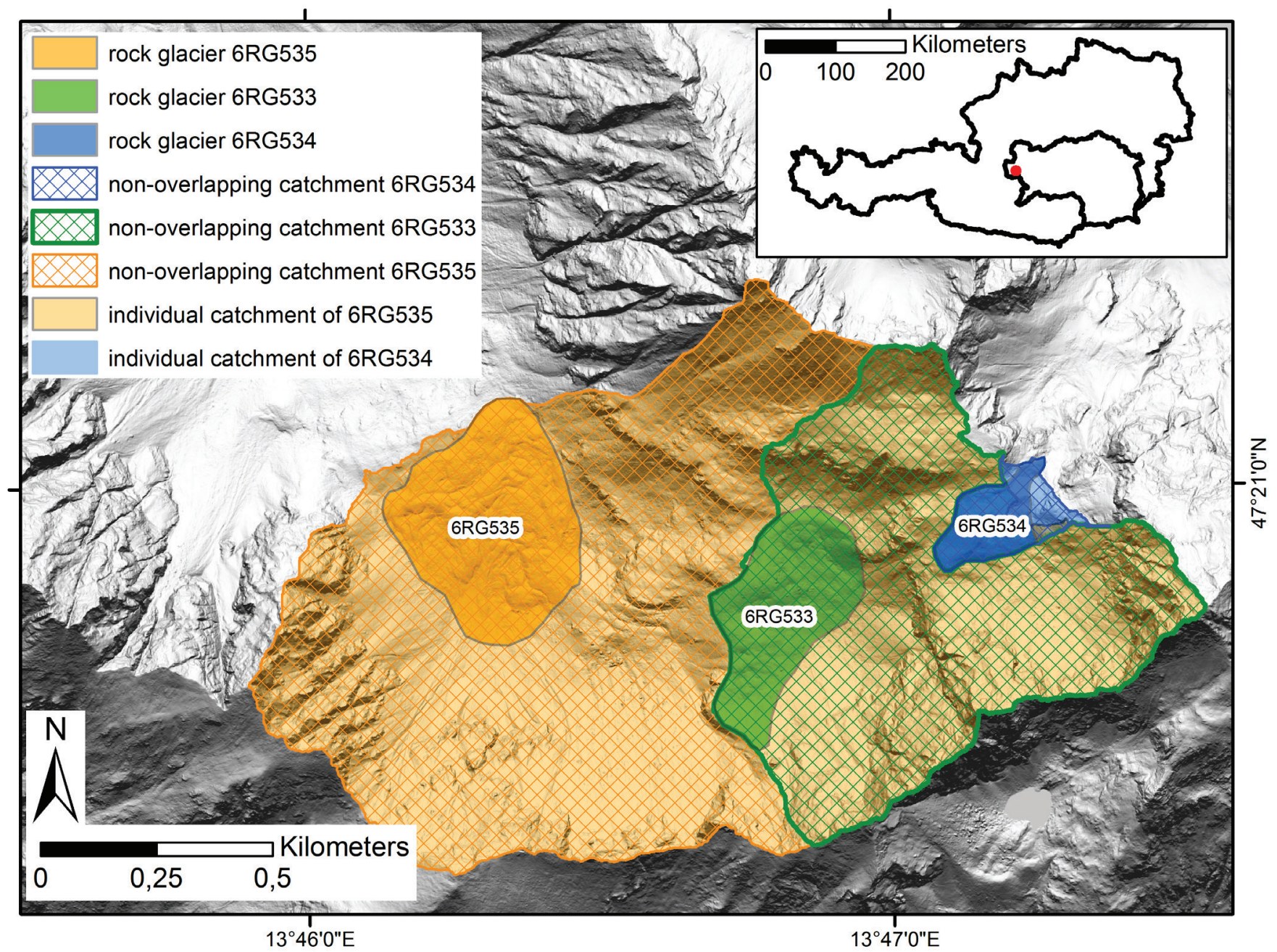

Figure 3: Catchment delineation showing an example of three rock glaciers that share (parts of) the same catchment. Note that 6 RG534 (dark blue polygon) is located on a saddle / drainage divide.

About $60 \%$ (3460) of the rock glaciers have been classified as relict, and $40 \%$ (2309) as intact. A combination of elevation and aspect has a direct influence on the activity status of the rock glaciers and was considered in the APIM (Boeckli et al., 2012) which was used to derive the activity status of the individual rock glaciers. This is presented in Figure 6a by showing box-whisker plots of minimum elevation of the landforms for eight different aspects (N, NE, E, SE, S, SW, W, NW) separately for relict versus intact rock glaciers. Relict rock glaciers are situated at lower elevations than intact ones (median difference of $457 \mathrm{~m}$ for all aspects), and southern aspects show higher rock glacier minimum elevations compared to rock glaciers with northern aspects (median difference of $290 \mathrm{~m}$ ). Intact rock glaciers with southern aspects are rather rare in contrast to relict rock glaciers (Figure 6b). Southwest oriented rock glaciers are rare (8 $\%$ for intact and $7 \%$ for relict ones). Figure $6 \mathrm{c}$ shows the spatial distribution of relict and intact rock glaciers.

The maximum length of rock glaciers varies from 17 to $1908 \mathrm{~m}$ with a median of $246 \mathrm{~m}$. The maximum width ranges from $30 \mathrm{~m}$ to $2762 \mathrm{~m}$ with a median of $172 \mathrm{~m}$. The majority of rock glaciers are tongue-shaped (78\%), $16 \%$ are lobate and only $6 \%$ are identified as complex forms.
When including protalus ramparts (652 out of the 5769 landforms), which are generally lobate in shape, tongueshaped landforms are reduced to $73 \%$. The median of the length to width ratio (ratioLWLf) is 2.06 (Figure 7a). The distribution of the landform area differs slightly for the individual federal states, with the highest median values for North Tyrol and the lowest for Vorarlberg (Figure 7b).

\subsection{Rock glacier catchment inventory}

The rock glacier catchment area of all 5769 rock glaciers sums up to almost $1280 \mathrm{~km}^{2}$ (Table 4). The largest areal share is observed in Tyrol, and the highest mean elevations of the catchments are also encountered there. Vorarlberg has the lowest areal share and Styria shows the lowest mean elevations of all federal states followed by Salzburg. The actual area that is drained through rock glaciers is small compared to the total land surface per federal state. However, if only the area above a certain elevation is considered, the areal percentage of rock glacier catchments becomes more important (Table 5). In Styria, $22.7 \%$ of the area above $2000 \mathrm{~m}$ a.s.l. is drained through rock glaciers although the rock glaciers cover only $2.3 \%$; in North Tyrol, $24.8 \%$ of the total area above $2500 \mathrm{~m}$ a.s.l. is drained through rock glaciers that have an areal share 


\begin{tabular}{|c|c|c|c|c|c|}
\cline { 2 - 6 } \multicolumn{1}{c|}{} & number & total area RG & \multicolumn{3}{c|}{ RG - elevation [m a.s.I.] } \\
\cline { 2 - 6 } \multicolumn{1}{c|}{} & {$[-]$} & {$\left[\mathrm{km}^{2}\right]$} & E-MIN & E-MED & E-MAX \\
\hline Styria & 713 & 40.3 & 652.0 & 2076.4 & 2976.3 \\
\hline Salzburg & 789 & 43.6 & 527.9 & 2236.4 & 2947.1 \\
\hline Carinthia & 816 & 40.6 & 475.5 & 2497.2 & 3128.2 \\
\hline East Tyrol & 609 & 30.5 & 1708.5 & 2467.5 & 3311.7 \\
\hline North Tyrol & 2539 & 136.5 & 1447.3 & 2143.5 & 2788.0 \\
\hline Vorarlberg & 303 & 11.4 & 831.7 & 2294.4 & 3311.7 \\
\hline total & 5769 & 303.0 & 475.5 & & \\
\hline
\end{tabular}

Table 3: Overview statistics of the rock glacier (RG) inventory. E-MIN= lowest value of the minimum elevations (minElevLf) of all rock glaciers in the area, $\mathrm{E}-\mathrm{MED}=$ median elevation of all the mean rock glacier elevations (meanElevLf), E-MAX= highest value of the maximum elevation (maxElevLf) of all rock glaciers in the area.

of $5.5 \%$. Considering the whole study area, $13.7 \%$ and $20.3 \%$ of the land surface are drained through rock glaciers, when taking elevations above 2000 and $2500 \mathrm{~m}$ a.s.l. into account, respectively. This elevation dependency is relevant considering altitudinal shifts in temperature and precipitation due to climate change and consequently changes in permafrost-affected areas.

Figure 8a presents the distribution of the mean elevation of the rock glacier catchments per federal state, illustrating the topographical influence already mentioned for the rock glaciers. An exception is Styria with the lowest mean value of $2004 \mathrm{~m}$ a.s.l.. The average ratio between rock glacier area and rock glacier catchment area is 0.27 ; i.e. the catchment area is on average 3.7 times larger than the rock glacier area. Differences for the individual federal states are shown in Figure $8 \mathrm{~b}$. The catchment areas in Styria tend to be the largest (median of $0.15 \mathrm{~km}^{2}$ ), whereas those in Vorarlberg are the smallest (median of $0.10 \mathrm{~km}^{2}$ ) (Figure 8c).

\subsection{Extended inventory analysis}

Figure 9a gives an overview of the individual mountain ranges of the Austrian Alps (Grassler, 1984). A detailed exemplary view of the Ötztal Alps and the Seckauer Tauern Range (easternmost mountain range of the Niedere Tauern Range) is shown in Figure 9b and 9c indicating also the activity status of the rock glaciers. Supplementary table S1 lists the data for all mountain ranges.

In the Seckauer Tauern Range a total of 127 relict rock glaciers are encountered (Figure 9e). Minimum elevations of the landforms, i.e. the front of the rock glaciers, are quite low $(\min =1276 /$ mean $=1767 / \max =2043 \mathrm{~m}$ a.s.l. $)$

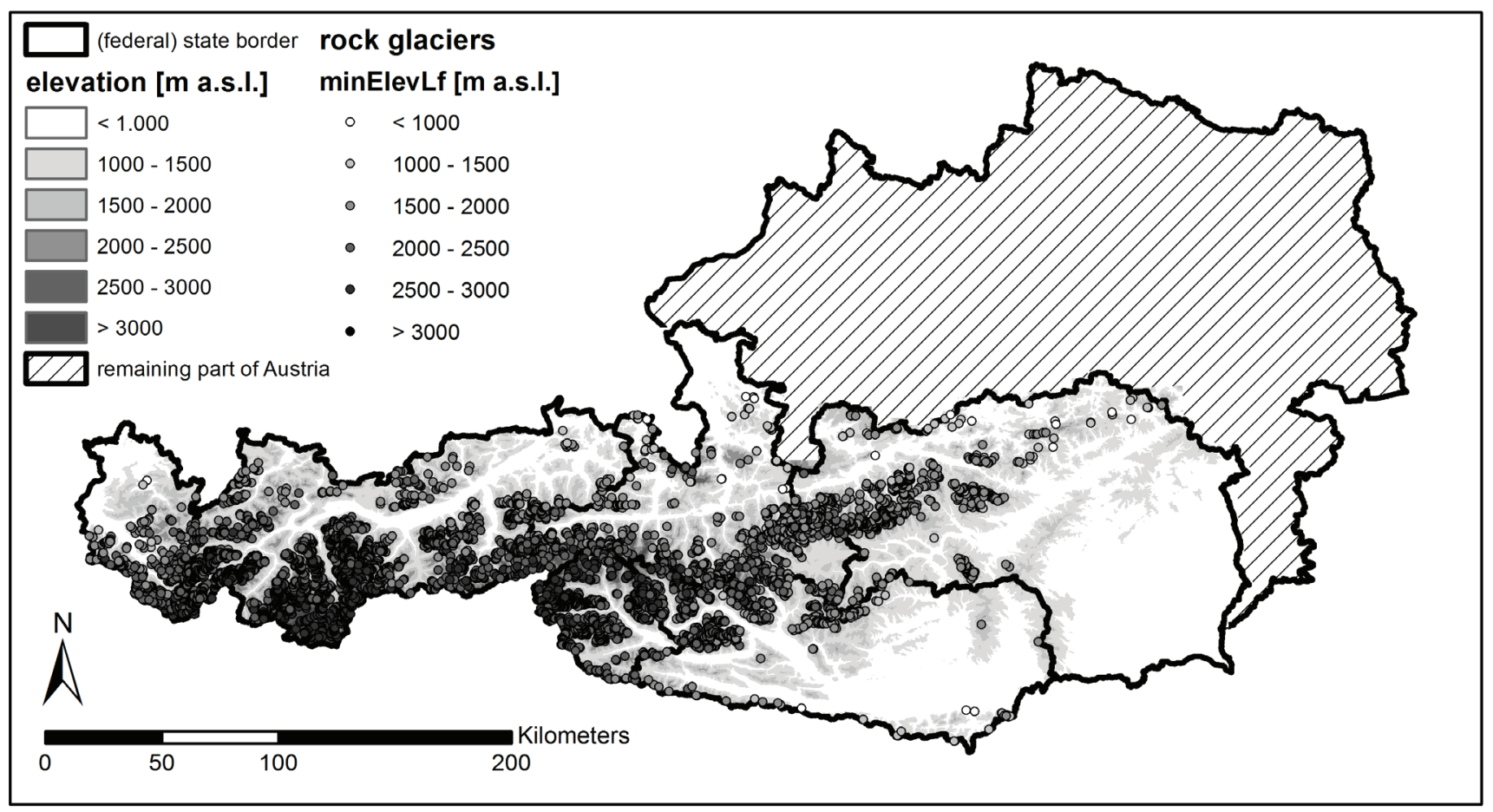

Figure 4: Distribution of rock glaciers in the Austrian Alps (borders of the federal states Vorarlberg, Tyrol, Salzburg, Styria and Carinthia and the national border of Austria). Rock glaciers are depicted as points by using their respective centroids and color-coded according to the elevation of their front ( $\min E l e v L f)$ in meters above sea level ( $m$ a.s.I.). 


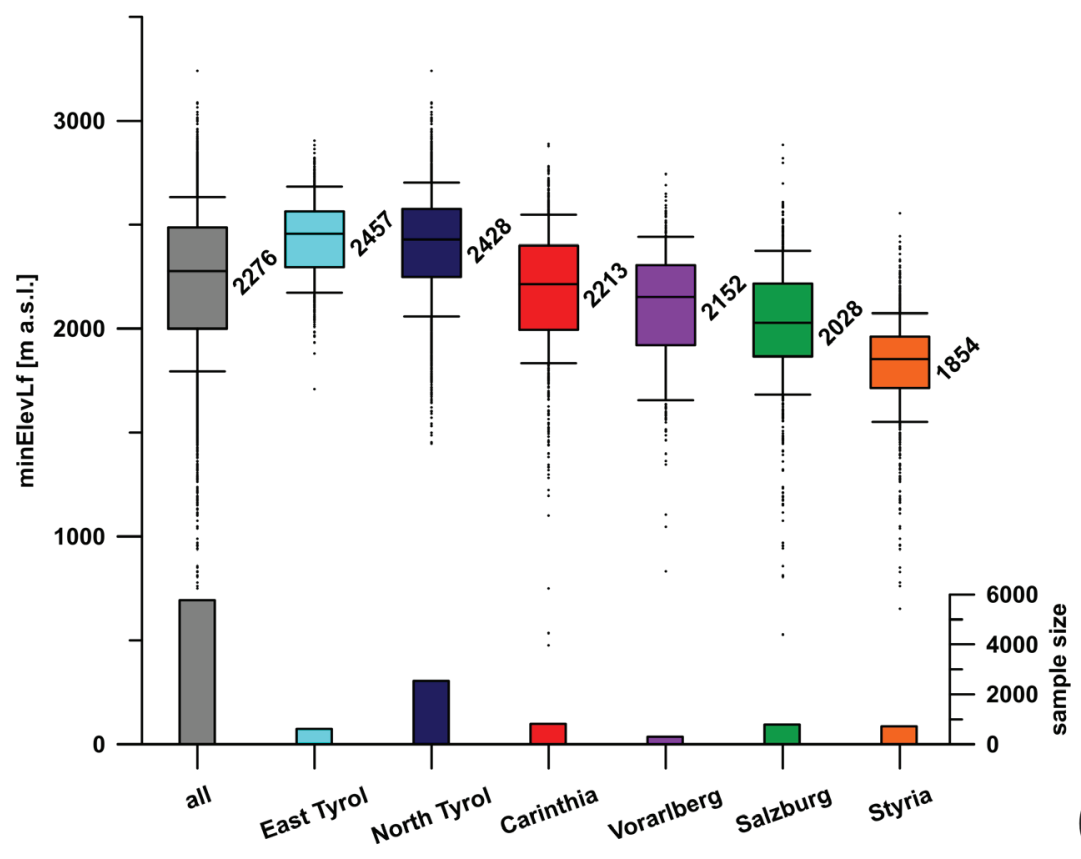

(a)
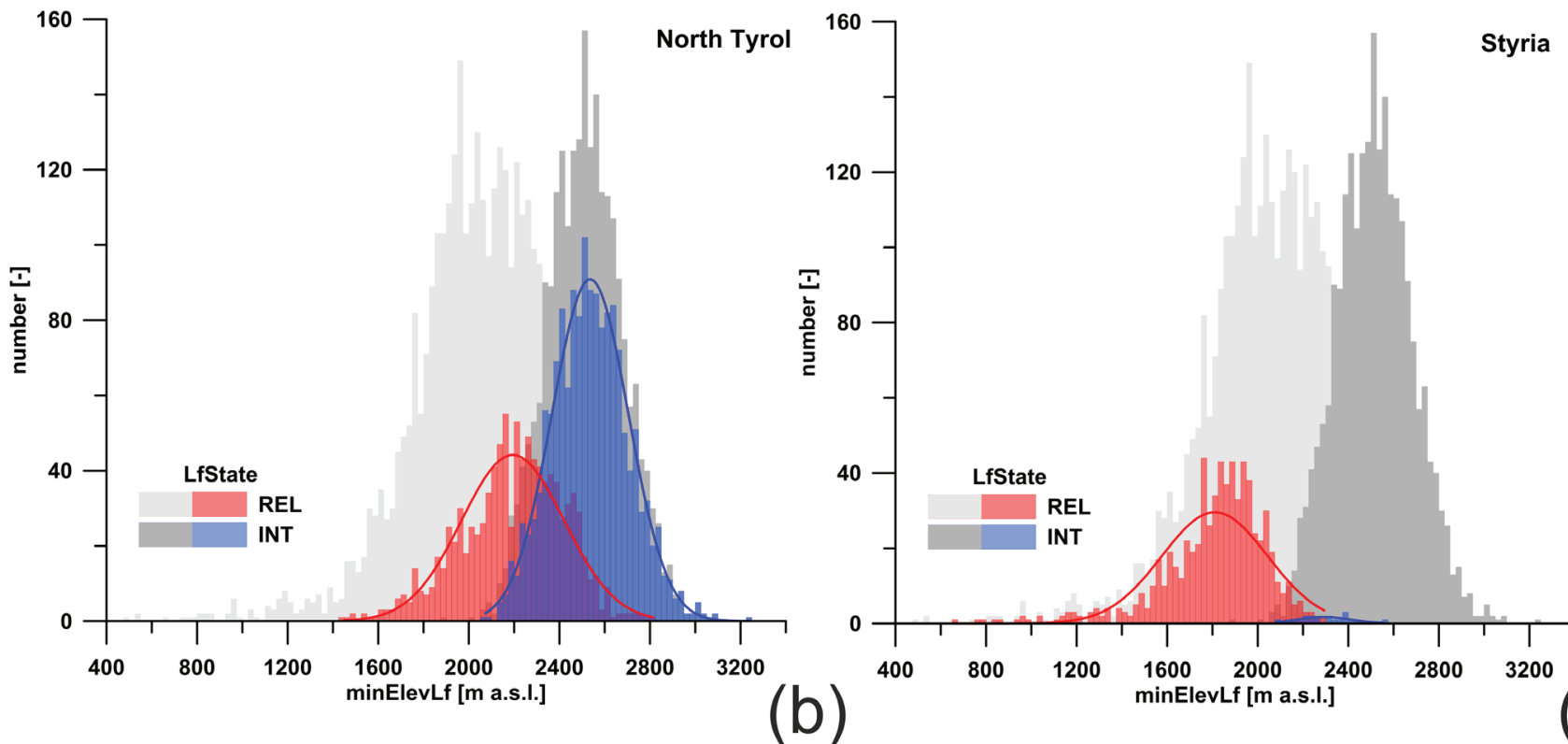

Figure 5: (a) Box-whisker plots of the elevation of the rock glacier front (minElevLf) of all mapped rock glaciers and per federal state. Tyrol is further separated into North and East Tyrol. Median values are given next to the boxes; sample sizes are shown in addition. For a distribution map of the rock glaciers see Figure 1. (b) and (c) show the elevation distribution of North Tyrol and Styria as histograms separated into relict and intact rock glaciers with the overall distribution of all mapped rock glaciers in Austria in grey colors in the background.

related to the topography and especially rather low elevations (highest peak Geierhaupt mountain $=2417 \mathrm{~m}$ a.s.I.) and related limited glaciation during LGM (Inset of Figure 1; van Husen, 2011). Periglacial processes might have acted here earlier during the Late Glacier period and was hence more efficient compared to areas further to the west.

In contrast to the relict rock glaciers in the Seckauer Tauern Range, a large number of intact rock glaciers is present in the Ötztal Alps (a total of 699 rock glaciers of which 556 are intact; Figure 9d). Their potential activity (active rock glaciers) and permafrost ice content make them more important for applied studies (see section 5).
Based on ten equally spaced bands (number of bands chosen to have a balance between a representative sample size per band and enough bands to observe some trend) subdividing the area from west to east and further into the three mountain super groups outlined in Figure 1, a general west - east trend was analyzed in Figure 10. Sample size per band demonstrates that in the Northern Calcareous Alps and especially in the Southern Calcareous Alps only a limited number of rock glaciers is present compared to the Central Eastern Alps. When considering also rock glaciers in Slovenia and Italy (Bollmann et al., 2012; Colucci et al., 2016), a more consistent picture would be provided for the Southern Calcareous Alps. 


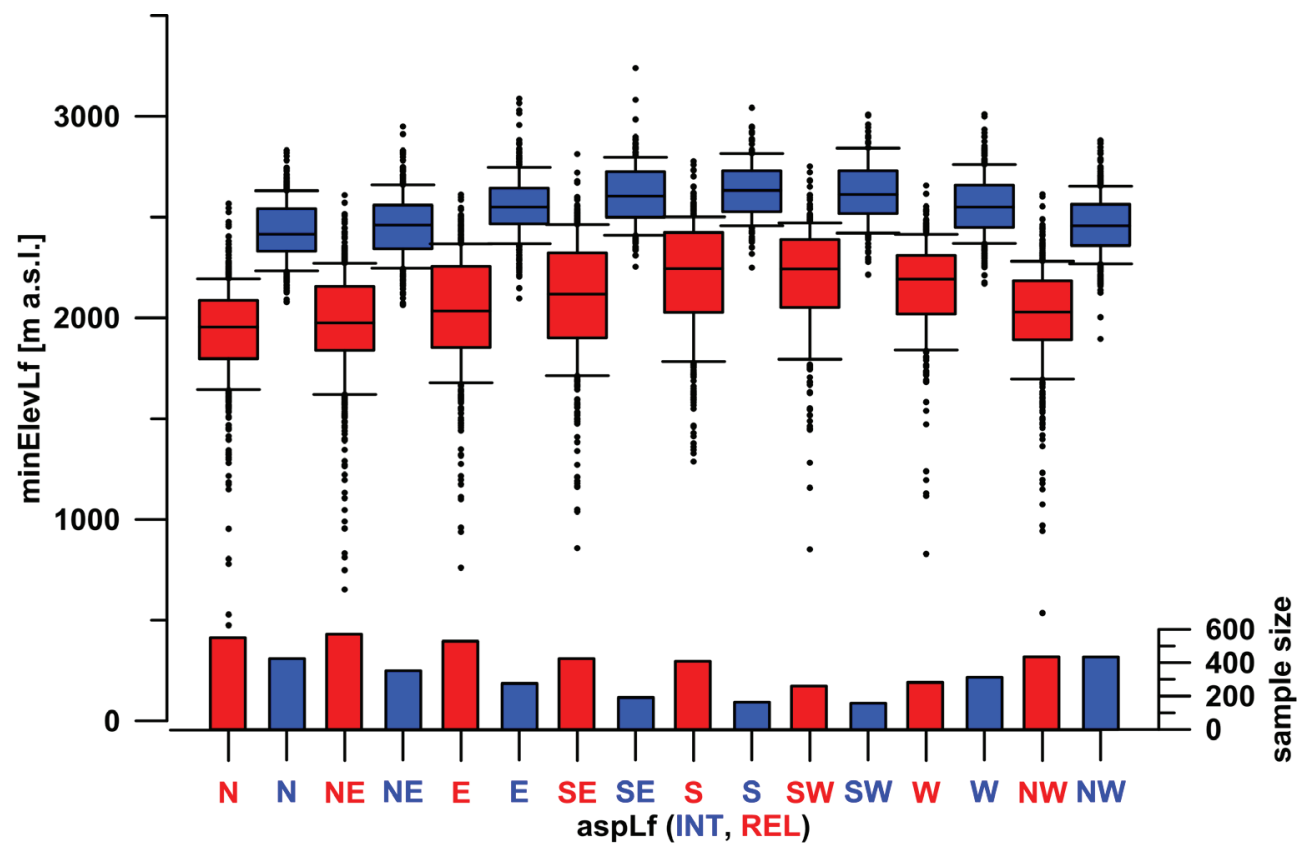

(a)

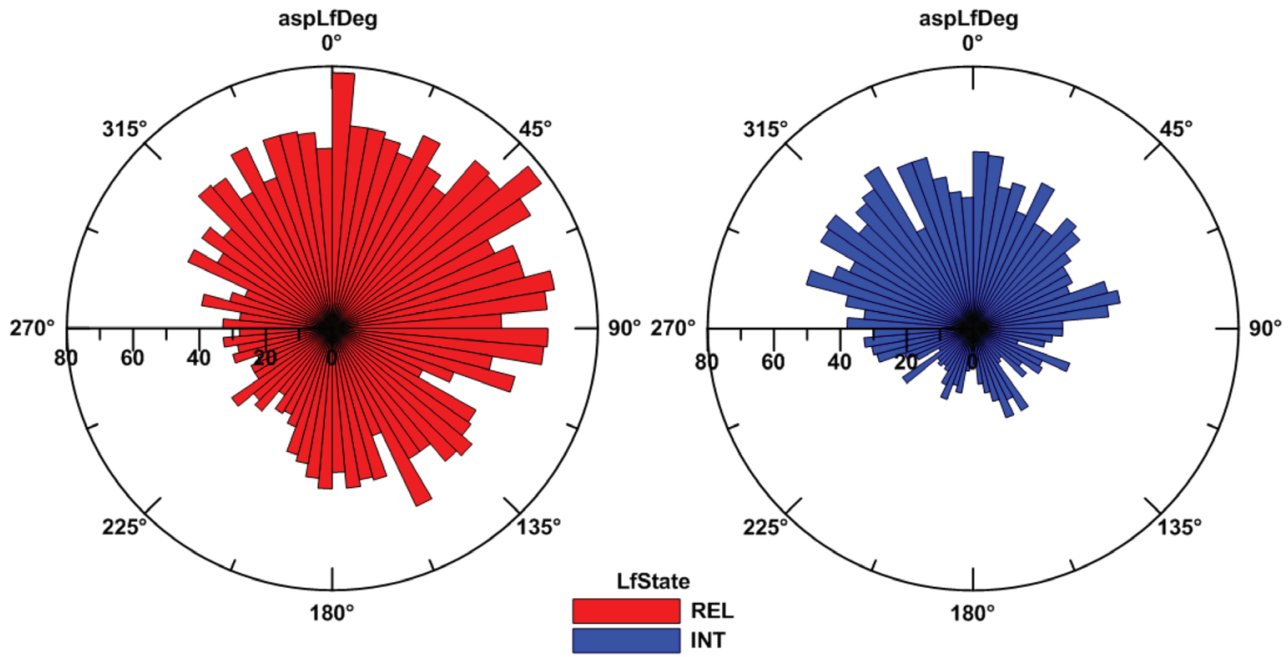

(b)

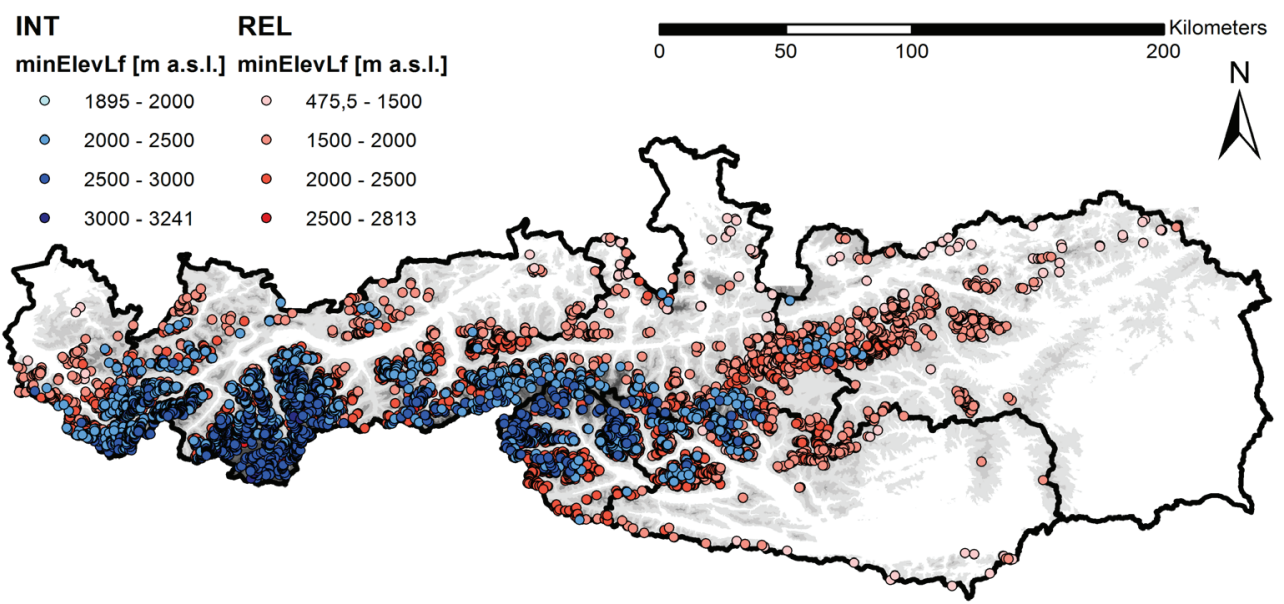

(c)

Figure 6: (a) Box-Whisker plots of minimum elevation of the landforms versus their aspects separated into relict and intact rock glaciers. (b) shows the aspect per activity state. (c) shows the spatial distribution of relict and intact rock glaciers within the study area of Austria with color intensity varied due to elevation. 

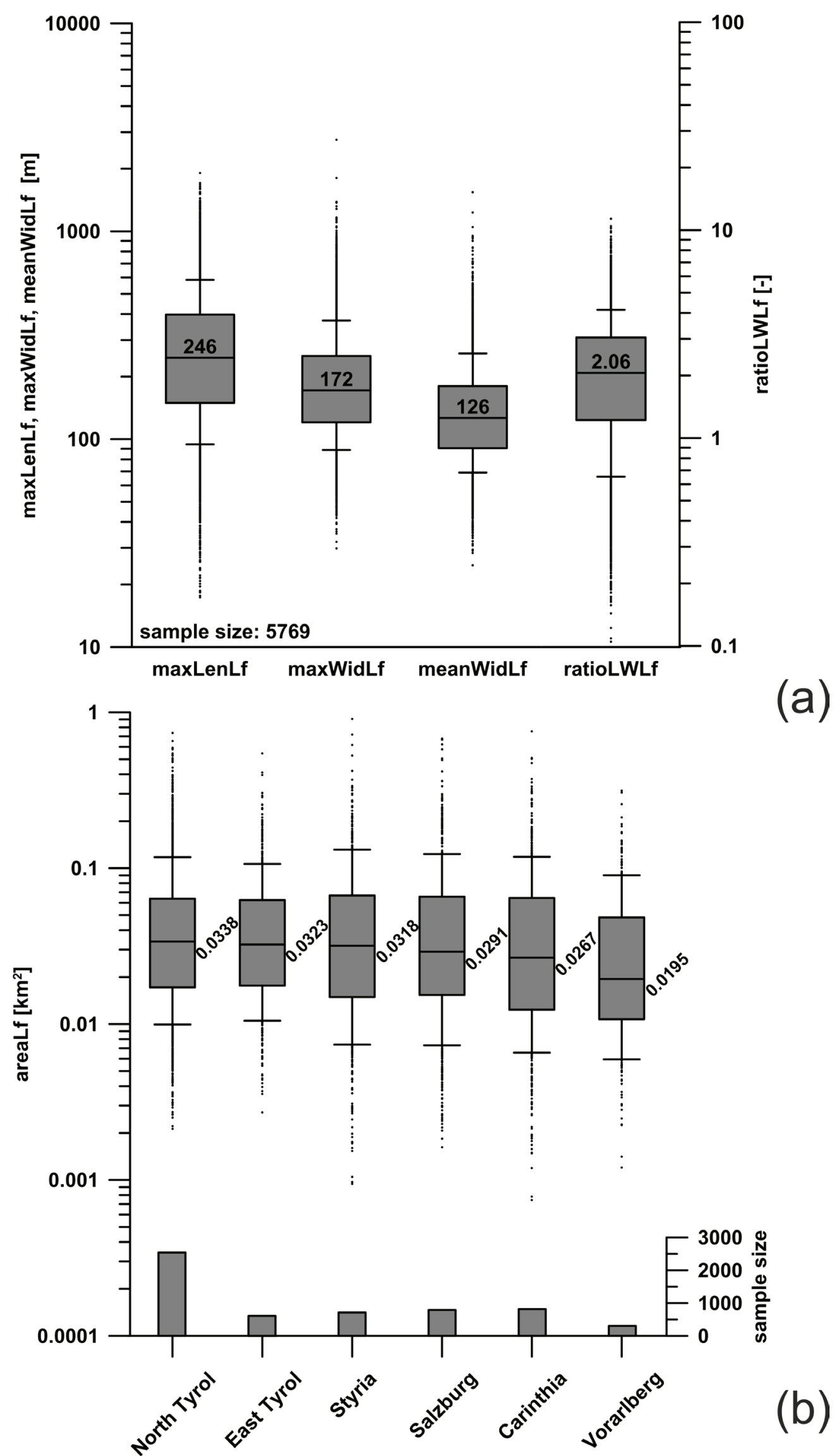

Figure 7: (a) Distribution of maximum length (maxLenLf), maximum width (maxWidLf), mean width (meanWidLf) and the ratio of maximum length to mean width (ratioLWLf) of all mapped rock glaciers. (b) Distribution of rock glaciers area per federal state and sample sizes; median values are depicted in the boxes. Note the log scale on the ordinate. 


\begin{tabular}{|c|c|c|c|c|c|}
\cline { 2 - 6 } \multicolumn{1}{c|}{} & number & RG catchment area & \multicolumn{3}{c|}{ RG catchment elevation [m a.s.I.] } \\
\cline { 2 - 6 } \multicolumn{1}{c|}{} & {$[-]$} & {$\left[\mathrm{km}^{2}\right]$} & E-MIN & E-MED & E-MAX \\
\hline Styria & 713 & 201.6 & 652.0 & 2004.4 & 2742.4 \\
\hline Salzburg & 789 & 190.0 & 527.9 & 2188.8 & 3146.3 \\
\hline Carinthia & 816 & 190.0 & 475.5 & 2365.0 & 3181.0 \\
\hline East Tyrol & 609 & 114.5 & 1708.5 & 2601.6 & 3571.0 \\
\hline North Tyrol & 2539 & 530.0 & 1447.3 & 2308.0 & 3100.5 \\
\hline Vorarlberg & 303 & 52.9 & 831.7 & 2441.1 & 3549.4 \\
\hline total & 5769 & 1279.0 & 475.5 & \\
\hline
\end{tabular}

Table 4: Overview statistics of the rock glacier $(\mathrm{RG})$ catchment inventory. E-MIN = lowest value of the minimum elevation (minEleCat) of all rock glacier catchments in the area, E-MED = median elevation of all the mean rock glacier catchment elevations (meanEleCat), E-MAX= highest value of the maximum elevation (maxEleCat) of all rock glacier catchments in the area.

A general west-east trend as already visible in the analysis of the federal states is even more apparent when referring to the Central Eastern Alps. In the far west (first band), median elevations of the rock glacier fronts (minElevLf) are $2301 \mathrm{~m}$ a.s.l., then rise up to $2509 \mathrm{~m}$ a.s.l. for the next $200 \mathrm{~km}$ and then decrease significantly towards the eastern part with median elevations of $1820 \mathrm{~m}$ a.s.l.. For the Northern Calcareous Alps, there is also a clear west-east trend; however, the decrease of rock glacier front elevations towards the east starts further west. Only five of the ten bands overlap the Southern Calcareous Alps, but also there, this decrease in rock glacier elevations is noticeable. Again, this is related to the topography and related glaciation history of the Austrian Alps (Moran et al., 2016).

Figure 11 presents an overview of all mapped rock glaciers on top of the groundwater bodies based on the national water management plan (NGP, 2015). There, only porous and predominantly porous, predominantly crystalline and karstifiable groundwater bodies are distinguished. This analysis is based on the attribute "GWK_Nr" found in the rock glacier inventory. Most of the rock glaciers are located in crystalline areas (91\%); none in (presumably) porous groundwater bodies and the remaining $9 \%$ of all mapped rock glaciers occur in areas related to karstifiable groundwater bodies.

\section{Discussion}

Both the rock glacier and the rock glacier catchment inventories presented here are considered as an important step towards a consistent approach to delineate and characterize periglacial landforms such as rock glaciers and their hydrological catchments.

The rock glacier inventory presented here is compiled from previous inventories (Stocker and Krainer, 2011; Krainer and Ribis, 2012; Kellerer-Pirklbauer et al., 2012, 2016, Lieb et al, 2012), checked and extended based on a consistent mapping base (ALS data of $1 \mathrm{~m}$ horizontal resolution) and attributed using consistent / homogenous and reproducible methods as far as possible. The dataset allows a comparison of different parts of the study area (Austrian Alps), such as different federal states or mountain ranges (see section 4).

For a comparison of the presented rock glacier inventory with inventories of other mountainous regions (e.g. of parts of Central Europe by Bollmann et al., 2012; Colucci et al., 2016; Onaca et al., 2017; Palma et al., 2017; Uxa and Mida, 2017; Fernandes et al., 2018; Popescu et al., 2017), a standardized inventory procedure as presented here is essential. The International Permafrost Association (IPA) is working on such a standard. The presented inventory procedure is contributing to this standardization.

The large amount of rock glaciers in the Austrian Alps and especially their abundance at higher elevations underlines the importance of these landforms also for the water cycle in high alpine regions (e.g. Jones et al., 2018; Winkler et al., 2018a). Particularly intact rock glaciers deserve special attention, as climate warming will ask for a better understanding of potential changes in their discharge dynamics due to melt out of the permafrost ice and potential changes in the storage capacities (e.g. Rogger et al., 2017). Besides a potential water storage in the form of permafrost ice within intact rock glaciers (e.g. Jones et al., 2018), the hydrogeological significance of rock glaciers is related to seasonal storage of water within these shallow aquifers and water flowing through them (e.g. Winkler et al., 2016). In addition to quantitative issues, a high-concentration heavy metal contamination in spring waters and permafrost ice of mainly active rock glaciers in Tyrol (including South Tyrol) was observed (Krainer et al., 2015; Thies et al., 2017; Ribis, 2017; Wagner et al., 2019a). Such qualitative challenges will need further research on a process-based understanding related to the origin of the observed high concentrations and especially its release from rock glacier bodies over time. This has consequences on drinking water quality of catchments in which rock glaciers are present, which is further relevant for the production of artificial snow in a winter tourism oriented area like the Ötztal Alps (Figure 9 $b, d)$, as the used water there needs to be drinking water quality (TWV).

The rock glacier catchment inventory allows for the first time in Austria to bring awareness to rock glaciers as important landforms for water management considerations in an integrative manner. Rock glaciers in general have a considerable hydrological storage / buffer capacity (Winkler et al., 2016, 2018a; Pauritsch et al., 2017). Thus, their influence on alpine / mountainous 

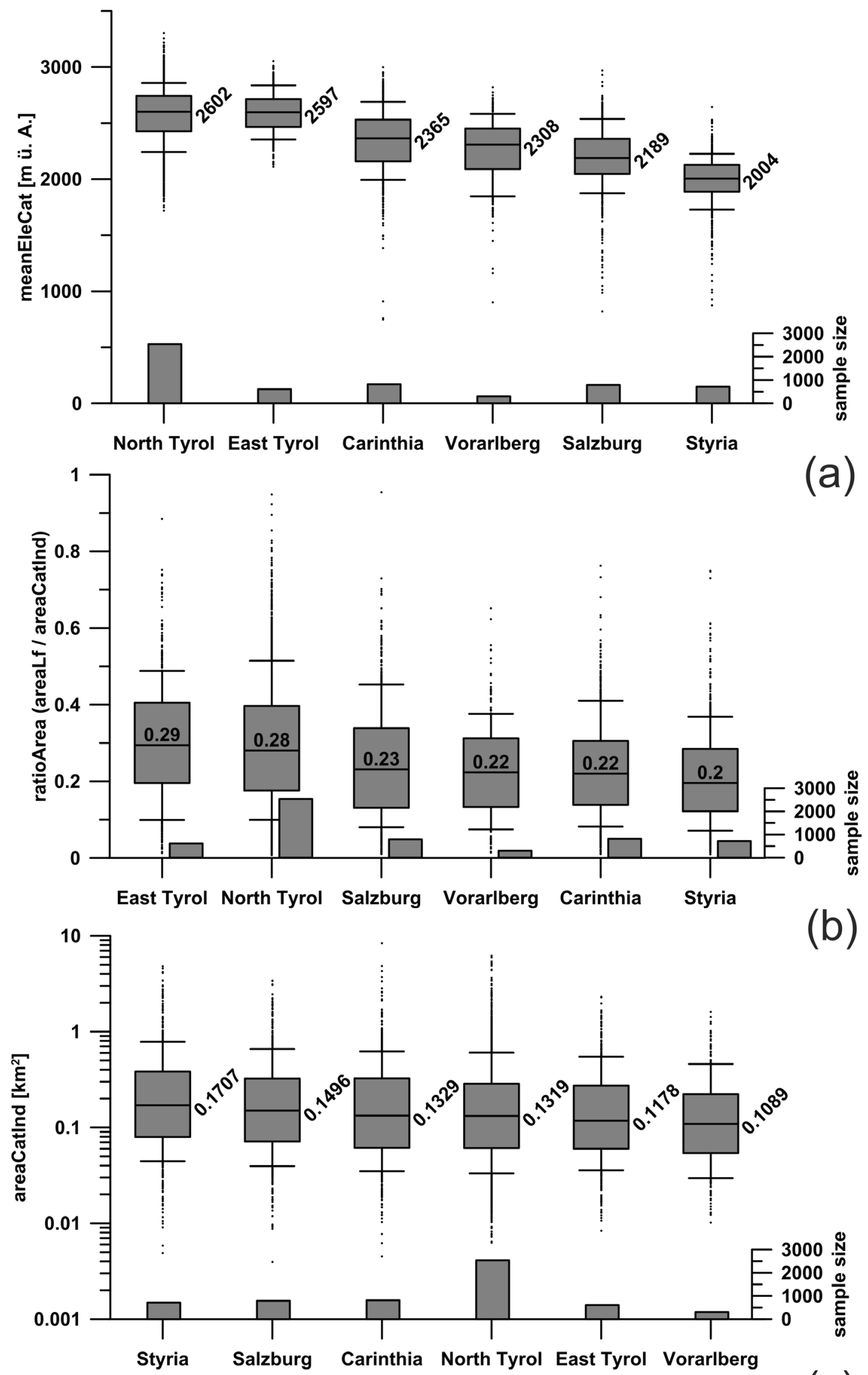

(c)

Figure 8: (a) Distribution of mean catchment elevations (meanEleCat), (b) ratio of rock glacier area to rock glacier catchment area (ratioArea) and (c) catchment area (areaCatInd) per federal state in decreasing ordered of the median values. Sample size is additionally shown. 


\begin{tabular}{|c|c|c|c|c|c|}
\hline & $\begin{array}{c}\text { land surface area } \\
{\left[\mathrm{km}^{2}\right]}\end{array}$ & $\begin{array}{c}\text { rock glacier area } \\
{\left[\mathrm{km}^{2}\right]}\end{array}$ & $\begin{array}{c}\text { percentage } \\
{[\%]}\end{array}$ & $\begin{array}{c}\text { catchment area } \\
{\left[\mathbf{k m}^{2}\right]}\end{array}$ & $\begin{array}{c}\text { percentage } \\
{[\%]}\end{array}$ \\
\hline \multicolumn{6}{|l|}{ Vorarlberg } \\
\hline total area & 2603.2 & 11.4 & 0.4 & 52.9 & 2.0 \\
\hline area $\geq 1500 \mathrm{~m}$ a.s.l. & 1077.4 & 11.2 & 1.0 & 52.5 & 4.9 \\
\hline area $\geq 2000 \mathrm{~m}$ a.s.l. & 415.1 & 6.8 & 1.6 & 38.3 & 9.2 \\
\hline area $\geq 2500 \mathrm{~m}$ a.s.l. & 53.8 & 0.4 & 0.8 & 7.7 & 14.3 \\
\hline area $\geq 3000 \mathrm{~m}$ a.s.l. & 1.6 & 0.0 & 0.0 & 0.0 & 1.7 \\
\hline \multicolumn{6}{|l|}{ North Tyrol } \\
\hline total area & 10629.9 & 136.5 & 1.3 & 530.0 & 5.0 \\
\hline area $\geq 1500 \mathrm{~m}$ a.s.l. & 6115.0 & 136.5 & 2.2 & 530.0 & 8.7 \\
\hline area $\geq 2000 \mathrm{~m}$ a.s.l. & 3442.7 & 128.4 & 3.7 & 508.9 & 14.8 \\
\hline area $\geq 2500 \mathrm{~m}$ a.s.l. & 1322.4 & 73.4 & 5.5 & 328.3 & 24.8 \\
\hline area $\geq 3000 \mathrm{~m}$ a.s.l. & 226.6 & 1.1 & 0.5 & 26.9 & 11.9 \\
\hline \multicolumn{6}{|l|}{ East Tyrol } \\
\hline total area & 2021.8 & 30.7 & 1.5 & 114.5 & 5.7 \\
\hline area $\geq 1500 \mathrm{~m}$ a.s.l. & 1600.3 & 30.7 & 1.9 & 114.5 & 7.2 \\
\hline area $\geq 2000 \mathrm{~m}$ a.s.l. & 1069.7 & 30.5 & 2.8 & 114.0 & 10.7 \\
\hline area $\geq 2500 \mathrm{~m}$ a.s.l. & 418.2 & 15.7 & 3.8 & 71.8 & 17.2 \\
\hline area $\geq 3000 \mathrm{~m}$ a.s.l. & 45.4 & 0.1 & 0.1 & 2.8 & 6.3 \\
\hline \multicolumn{6}{|l|}{ Salzburg } \\
\hline total area & 7161.0 & 43.6 & 0.6 & 190.0 & 2.7 \\
\hline area $\geq 1500 \mathrm{~m}$ a.s.l. & 3019.8 & 40.7 & 1.3 & 182.1 & 6.0 \\
\hline area $\geq 2000 \mathrm{~m}$ a.s.l. & 1235.0 & 25.3 & 2.0 & 136.0 & 11.0 \\
\hline area $\geq 2500 \mathrm{~m}$ a.s.l. & 259.2 & 3.2 & 1.2 & 19.3 & 7.4 \\
\hline area $\geq 3000 \mathrm{~m}$ a.s.l. & 23.6 & 0.0 & 0.0 & 0.1 & 0.3 \\
\hline \multicolumn{6}{|l|}{ Styria } \\
\hline total area & 16419.2 & 40.3 & 0.2 & 201.6 & 1.2 \\
\hline area $\geq 1500 \mathrm{~m}$ a.s.l. & 2505.5 & 37.0 & 1.5 & 190.8 & 7.6 \\
\hline area $\geq 2000 \mathrm{~m}$ a.s.l. & 375.3 & 8.5 & 2.3 & 85.3 & 22.7 \\
\hline area $\geq 2500 \mathrm{~m}$ a.s.l. & 4.2 & 0.0 & 0.4 & 0.4 & 10.4 \\
\hline area $\geq 3000 \mathrm{~m}$ a.s.l. & 0.0 & 0.0 & 0.0 & 0.0 & 0.0 \\
\hline \multicolumn{6}{|l|}{ Carinthia } \\
\hline total area & 9543.9 & 40.5 & 0.4 & 190.0 & 2.0 \\
\hline area $\geq 1500 \mathrm{~m}$ a.s.l. & 2693.8 & 38.4 & 1.4 & 185.7 & 6.9 \\
\hline area $\geq 2000 \mathrm{~m}$ a.s.l. & 1040.4 & 29.2 & 2.8 & 153.7 & 14.8 \\
\hline area $\geq 2500 \mathrm{~m}$ a.s.l. & 273.9 & 5.4 & 2.0 & 45.4 & 16.6 \\
\hline area $\geq 3000 \mathrm{~m}$ a.s.l. & 25.0 & 0.0 & 0.0 & 0.5 & 2.1 \\
\hline \multicolumn{6}{|l|}{ total } \\
\hline total area & 48379.0 & 303.0 & 0.6 & 1279 & 2.6 \\
\hline area $\geq 1500$ m a.s.l. & 17011.9 & 294.5 & 1.7 & 1255.6 & 7.4 \\
\hline area $\geq 2000 \mathrm{~m}$ a.s.l. & 7578.1 & 228.7 & 3.0 & 1036.1 & 13.7 \\
\hline area $\geq 2500 \mathrm{~m}$ a.s.l. & 2331.7 & 98.2 & 4.2 & 472.9 & 20.3 \\
\hline area $\geq 3000 \mathrm{~m}$ a.s.l. & 322.3 & 1.2 & 0.4 & 30.4 & 9.4 \\
\hline
\end{tabular}

Table 5: Overview of land surface areas, rock glacier areas and rock glacier catchment areas per federal state and in total considering the total area or the area above a certain elevation (1500, 2000, 2500 and $3000 \mathrm{~m}$ a.s.l.). 

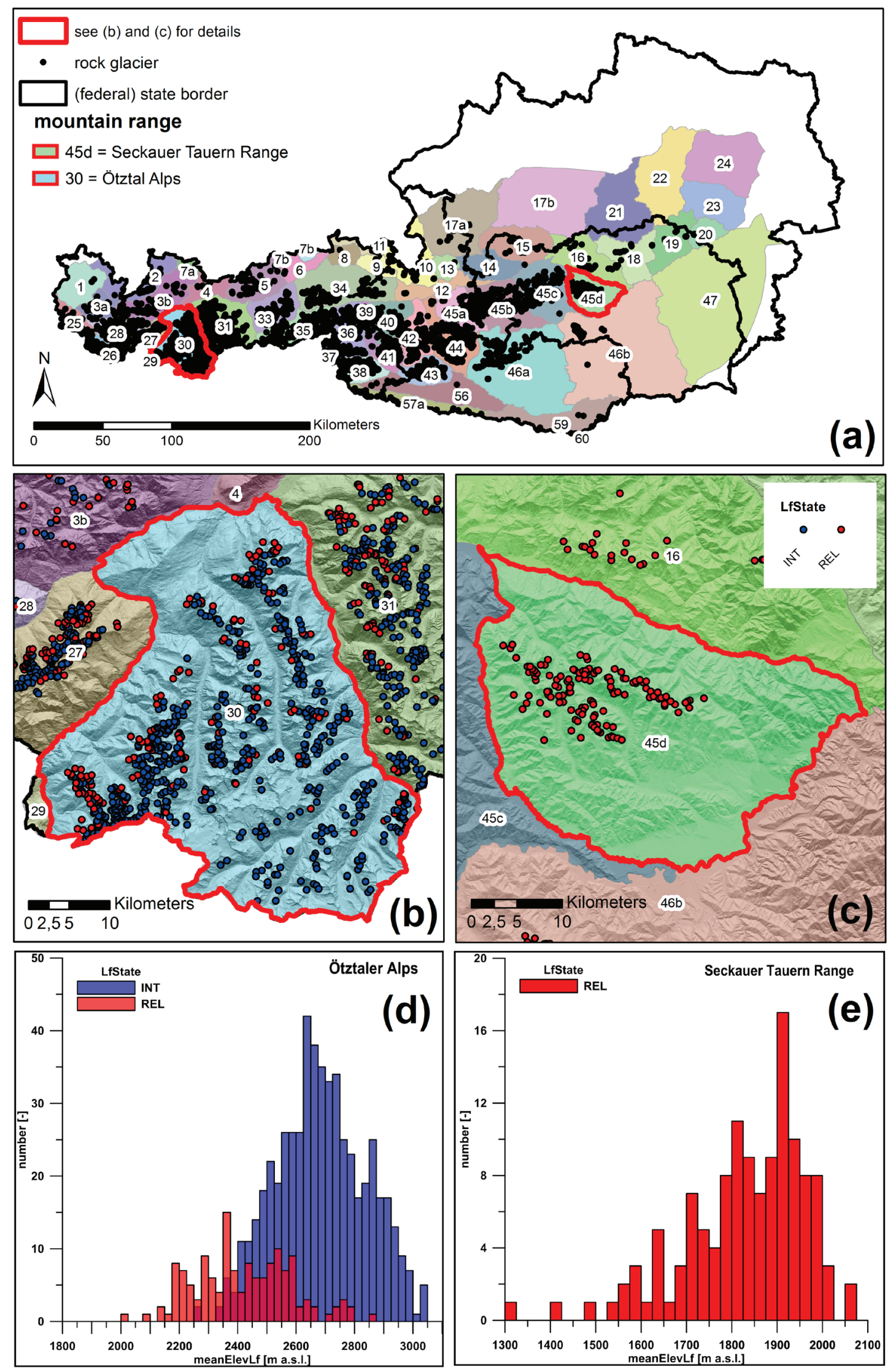

Figure 9: (a) Overview of rock glaciers and the mountain ranges in which they are located based on Grassler (1984); (b, c) details from the Ötztal Alps and the Seckauer Tauern Range where the activity state is color coded for intact (INT) and relict landforms (REL); (d, e) histogram of relict and intact rock glaciers for the respective mountain range. Note the different scaling of the axes. In the supplement table S1 a list of all mountain ranges in which rock glaciers were mapped is presented, including the number of rock glaciers, the number of relict and intact rock glaciers as well as the area of the rock glaciers and their catchment area. 


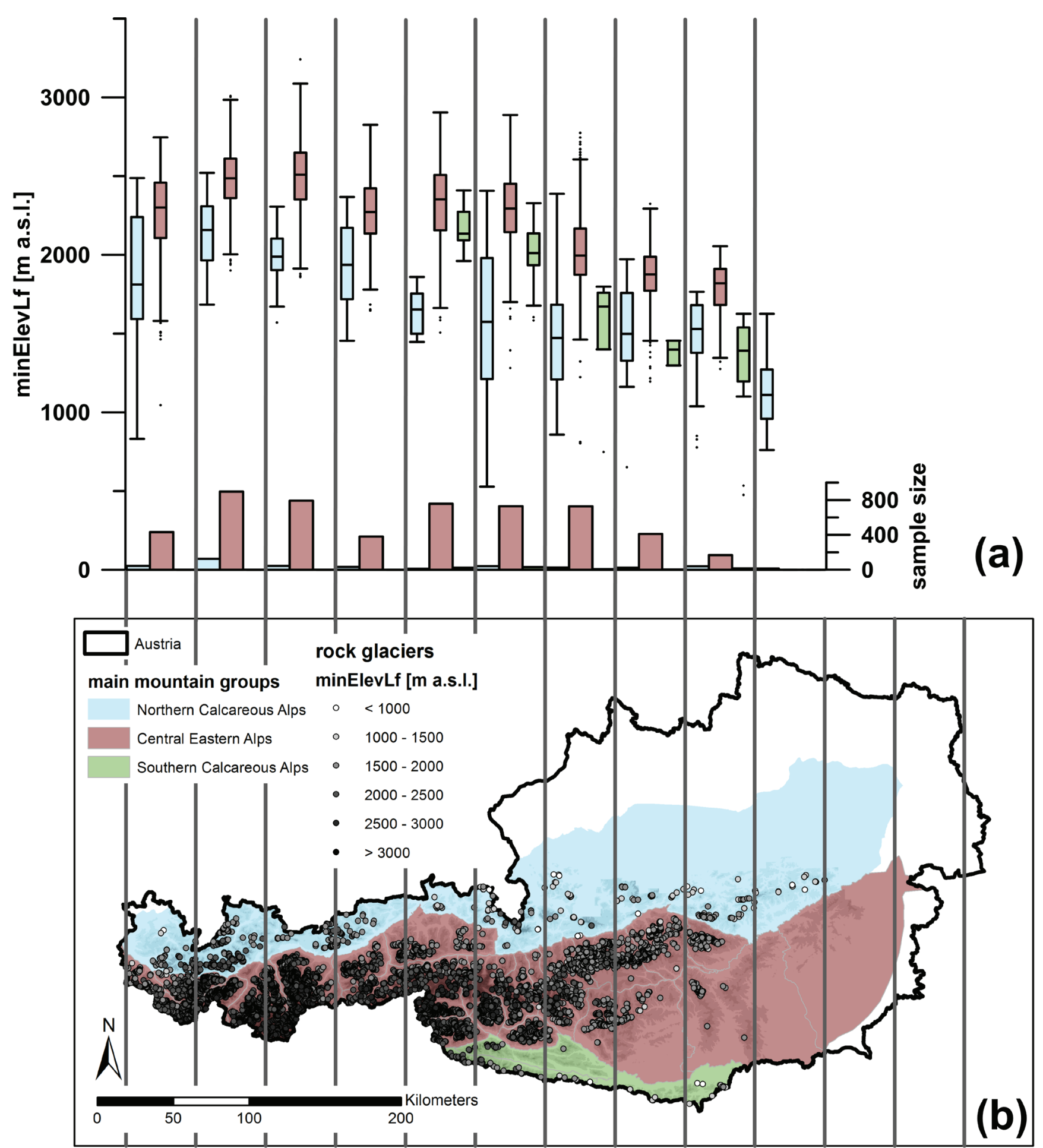

Figure 10: West-east trend of minimum rock glacier elevations (minElevLf) based on a subdivision into the three main mountain groups and ten equally spaced bands from west to east across the study area (a) Box-whisker plots of minElevLf per band and super group and the respective sample sizes. Note that rock glaciers in the Northern Calcareous and especially Southern Calcareous Alps are rare. (b) Overview map of study area, the main mountain groups and the ten bands used for the analysis in (a). 
- $\quad$ rock glaciers within karstifiable groundwater bodies

- $\quad$ rock glaciers within crystalline groundwater bodies

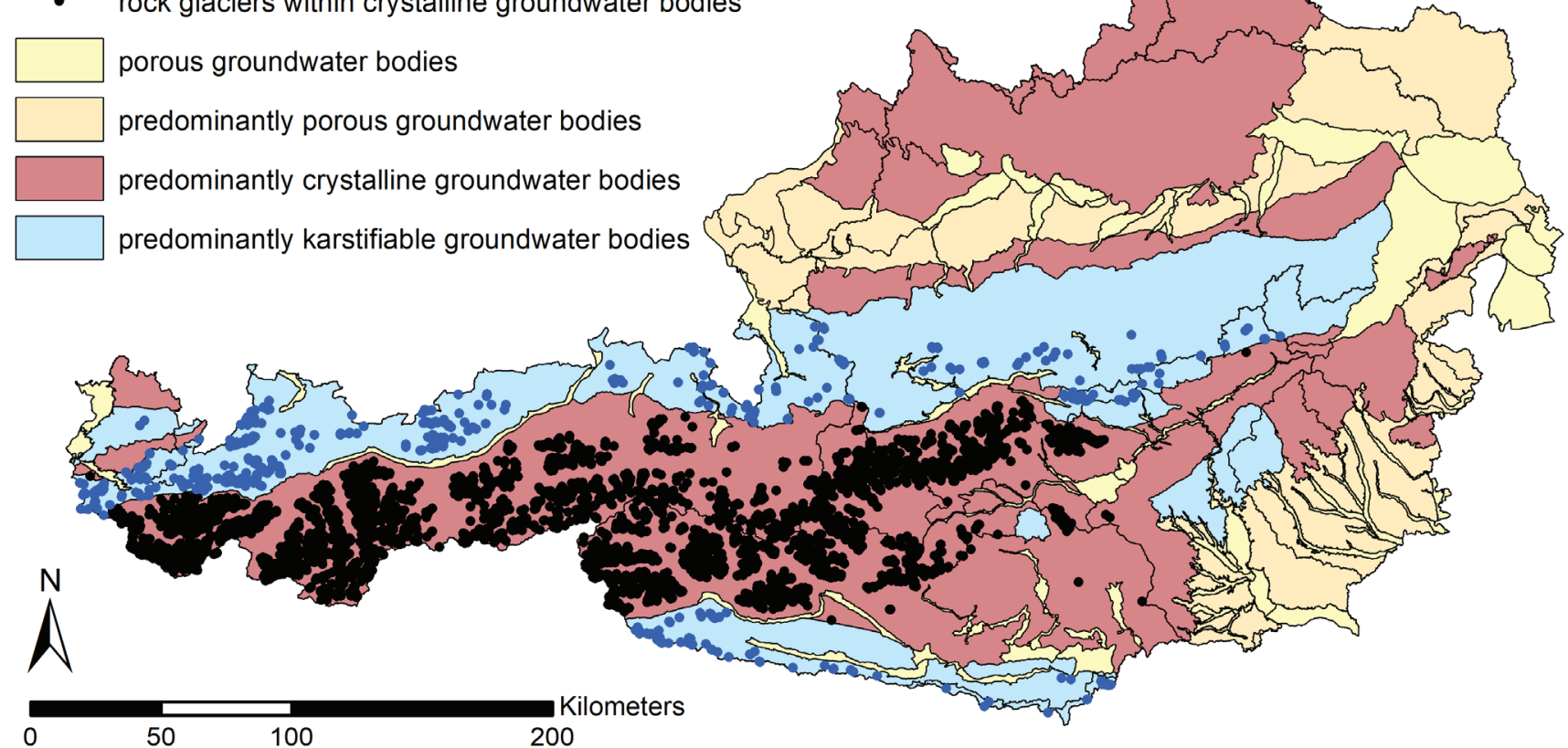

Figure 11: Overview of the various groundwater bodies within the study area differentiated into (predominantly) porous groundwater bodies, predominantly crystalline and predominantly karstifiable groundwater bodies (NGP, 2015) and related rock glaciers (as centroids). Note that there are no rock glaciers observed in (predominantly) porous groundwater bodies; color-coding of rock glaciers separated into blue (related to karstifiable groundwater bodies) and black (related to crystalline groundwater bodies) centroids.

headwaters needs a better understanding (e.g. Rogger et al., 2017). Although the areal proportion of rock glacier catchments to the total land surface is rather small, their hydrologic impact is often considerable in mountainous regions and at higher elevations, respectively (see section 4). These landforms might contain aquifers with relatively large springs (mean annual discharge $>10 \mathrm{l} / \mathrm{s}$ ) in crystalline catchments, where usually small springs are found (e.g. Untersweg and Schwendt, 1995, 1996; Winkler et al., 2016). Moreover, the storage capacity of rock glaciers has a considerable impact on the discharge dynamics of downstream river sections, where on a daily base, water drained from rock glaciers can contribute a multiple of their areal proportions (Wagner et al., 2016).

In karstifiable groundwater bodies (e.g. Karwendel), the complex interaction between rock glaciers and drainage pattern needs further investigations, as springs at the front of rock glaciers - as usually observed in crystalline rocks - are absent. Therefore, their hydrogeological relevance is largely unknown until now. Furthermore, the delineation of their orographic catchment area is likely different from their hydrological catchment area.

Differences in elevation distribution of rock glaciers in the Austrian Alps are to a large degree a reflection of the topography and its glaciation history or absence of glaciation (e.g. Ehlers et al., 2011; Kellerer-Pirklbauer et al., 2012). For example, in the Seckauer Tauern Range (Figure 9c,e) where glaciation was limited during LGM (Inset of Figure 1; van Husen, 2011), a relatively high age of these landforms is suggested (about 12-13 ka BP;
Nagl, 1976). Relative age dating by morphological criterions or using Schmidt-Hammer method is reported for the Niedere Tauern Range by Nagl, (1976) and Rode and Kellerer-Pirklbauer (2012), respectively. However, absolute age dating has not been done yet in this area (e.g. by using surface exposure dating; Ivy-Ochs and Kober, 2008). Interests in palaeo-climate reconstruction may focus on an area like this and rock glaciers that are located at an even lower elevation.

Concerning the west-east trend of rock glacier elevations reported in section 4.3, a combination of the presented rock glacier inventory with those of neighboring areas, e.g. towards the south with Slovenia and Italy is worth pursuing. Boccali et al. (2019) reported 52 mainly relict rock glaciers (88\% relict) and Colucci et al. (2016) 66 protalus ramparts (16 of them likely still active) from the north-eastern-most region of Italy (Friuli Venezia Giulia region) and Slovenia. More importantly, for South Tyrol Bollmann et al. (2012) reported 1467 rock glaciers, of which 294 are intact and the remaining $80 \%$ of the rock glaciers are relict. Combining these inventories, a total number of 7355 rock glaciers and protalus ramparts is reported. On average, $64 \%$ of these landforms are relict and $36 \%$ intact. As rock glaciers are climatically more resilient than glaciers and intact rock glaciers hold possibly hydrologically valuable ice volumes (Jones et al., 2019), a better understanding of potential changes over time in storage capacities and discharge dynamics is required for these landforms, particularly in the light of climate change (Winkler et al., 2018; Jones et al., 2019). 


\begin{tabular}{|c|c|c|c|c|c|c|}
\hline Gebirgsgruppe & AV-Nr. & $\#[-]$ & \#REL [-] & \#INT [-] & $\operatorname{areaLf}\left[\mathrm{km}^{2}\right]$ & areaCat $\left[\mathrm{km}^{2}\right]$ \\
\hline Allgäuer Alpen & 2 & 40 & 37 & 3 & 1.60 & 10.37 \\
\hline Ankogel-Gruppe & 44 & 314 & 184 & 130 & 18.47 & 87.18 \\
\hline Berchtesgadener Alpen & 10 & 29 & 26 & 3 & 1.32 & 6.71 \\
\hline Brandenberger Alpen (Rofan-Gebirge) & 6 & 2 & 2 & 0 & 0.19 & 0.77 \\
\hline Bregenzerwald-Gebirge & 1 & 2 & 2 & 0 & 0.02 & 0.07 \\
\hline Chiemgauer Alpen & 11 & 5 & 5 & 0 & 0.21 & 1.08 \\
\hline Dachstein-Gebirge & 14 & 8 & 6 & 2 & 1.29 & 6.14 \\
\hline Ennstaler Alpen & 16 & 36 & 36 & 0 & 2.08 & 12.18 \\
\hline Gailtaler Alpen & 56 & 14 & 13 & 1 & 0.54 & 3.50 \\
\hline Glockner-Gruppe & 40 & 61 & 40 & 21 & 3.10 & 14.82 \\
\hline Goldberg-Gruppe & 42 & 175 & 130 & 45 & 7.54 & 34.97 \\
\hline Granatspitz-Gruppe & 39 & 49 & 22 & 27 & 3.16 & 10.89 \\
\hline Hochschwab-Gruppe & 18 & 13 & 13 & 0 & 0.67 & 4.00 \\
\hline Kaiser-Gebirge & 8 & 9 & 9 & 0 & 0.22 & 1.62 \\
\hline Karawanken und Bachergebirge & 59 & 17 & 17 & 0 & 2.49 & 9.97 \\
\hline Karnischer Hauptkamm & $57 a$ & 45 & 44 & 1 & 2.62 & 11.23 \\
\hline Karwendel & 5 & 66 & 59 & 7 & 4.32 & 23.55 \\
\hline Kitzbüheler Alpen & 34 & 169 & 163 & 6 & 5.69 & 21.86 \\
\hline Kreuzeck-Gruppe & 43 & 217 & 191 & 26 & 7.84 & 32.68 \\
\hline Lavanttaler Alpen & $46 \mathrm{~b}$ & 40 & 40 & 0 & 2.02 & 11.62 \\
\hline Lechquellen-Gebirge & $3 a$ & 32 & 26 & 6 & 1.59 & 6.19 \\
\hline Lechtaler Alpen & $3 b$ & 96 & 53 & 43 & 4.08 & 22.94 \\
\hline Loferer und Leoganger Steinberge & 9 & 4 & 4 & 0 & 0.23 & 1.31 \\
\hline Mürzsteger Alpen & 19 & 8 & 8 & 0 & 0.86 & 5.38 \\
\hline Nockberge & $46 a$ & 184 & 184 & 0 & 9.75 & 40.18 \\
\hline Ötztaler Alpen & 30 & 699 & 143 & 556 & 40.71 & 154.80 \\
\hline Radstädter Tauern & $45 a$ & 131 & 131 & 0 & 8.85 & 43.35 \\
\hline Rätikon & 25 & 76 & 69 & 7 & 3.69 & 18.91 \\
\hline Rax-Schneeberg-Gruppe & 20 & 1 & 1 & 0 & 0.01 & 0.38 \\
\hline Rieserferner-Gruppe & 37 & 19 & 4 & 15 & 1.18 & 2.59 \\
\hline Rottenmanner und Wölzer Tauern & $45 c$ & 217 & 217 & 0 & 9.94 & 44.98 \\
\hline Salzburger Schieferalpen & 12 & 3 & 3 & 0 & 0.01 & 0.08 \\
\hline Salzkammergut-Berge & $17 a$ & 15 & 15 & 0 & 0.75 & 3.29 \\
\hline Samnaun-Gruppe & 27 & 292 & 95 & 197 & 12.93 & 43.56 \\
\hline Schladminger Tauern & $45 \mathrm{~b}$ & 349 & 327 & 22 & 17.23 & 88.31 \\
\hline Schober-Gruppe & 41 & 215 & 81 & 134 & 11.26 & 49.28 \\
\hline Seckauer Tauern & $45 d$ & 127 & 127 & 0 & 12.15 & 59.28 \\
\hline Silvretta & 26 & 225 & 69 & 156 & 10.75 & 34.57 \\
\hline Stubaier Alpen & 31 & 502 & 193 & 309 & 32.40 & 128.80 \\
\hline Tennen-Gebirge & 13 & 3 & 3 & 0 & 0.11 & 0.59 \\
\hline Totes Gebirge & 15 & 16 & 16 & 0 & 1.20 & 9.91 \\
\hline Tuxer Alpen & 33 & 181 & 123 & 58 & 6.27 & 24.84 \\
\hline Venediger-Gruppe & 36 & 286 & 117 & 169 & 14.50 & 47.60 \\
\hline Verwall-Gruppe & 28 & 328 & 143 & 185 & 14.38 & 56.65 \\
\hline Villgratener Berge & 38 & 219 & 180 & 39 & 9.07 & 36.82 \\
\hline Wetterstein-Gebirge und Mieminger Kette & 4 & 8 & 5 & 3 & 0.70 & 4.15 \\
\hline Ybbstaler Alpen & 21 & 1 & 1 & 0 & 0.07 & 0.42 \\
\hline Zillertaler Alpen & 35 & 221 & 83 & 138 & 12.99 & 44.65 \\
\hline
\end{tabular}

Table S1: List of all mountain ranges using the division of the Alpine Club classification of the Eastern Alps with numbers given in Grassler (1984) in which rock glaciers were mapped, including the number of rock glaciers (\#), the number of relict (\#REL) and intact (\#INT) rock glaciers as well as the area of the rock glaciers landforms (areaLf) and their catchment area (areaCat). 
The rock glacier inventory presented here is seen as a first step towards a systematic approach for the Austrian Alps (and adjacent areas). Certain subjectivities remain, as for instance the actual genesis of the landforms, particularly the problem of equifinality for relict landforms (e.g. Jarman et al., 2013; Hedding, 2016; Anderson et al., 2018; Bardinoni et al., 2019). Therefore, this first complete inventory for Austria with a transparent and reproducible assignment of attributes is not a final product but intended to spur further discussion about (poly)genesis of these discrete debris accumulations.

\section{Conclusion}

For the first time a polygon-based rock glacier inventory of the Austrian Alps was compiled based on available high resolution digital elevation data and earlier inventories. The former aspect allowed a better identification of such landforms in lower areas that are extensively covered by forests or shrubs. We identified 5769 rock glaciers, which increased the number of rock glaciers in Austria reported from previous inventories by 1219 landforms. A consistent attribution was applied which is crucial for further analysis and comparison with other inventories. The dataset presented here will be of interest for paleo-climate research in the Alps. Particularly observed trends from west to east that are related to elevation and activity of the landforms provide indications of the former extent of periglacial areas. In addition, the determination of absolute ages of these landforms would be a very helpful completion and should be a future research interest.

The relevance of these landforms for the hydrogeology of high Alpine regions was highlighted by extending the landform inventory with a catchment inventory. An area of almost $1280 \mathrm{~km}^{2}$ is drained through rock glaciers. Based on their storage capacity and the high quantity of these landforms they are relevant for water resources management concerning water quantity and also water quality of alpine catchments in the light of climate change. Further, rock glaciers and their impact on the drainage behavior of alpine catchments are essential for this sensitive ecosystem.

\section{Acknowledgements}

This work was co-funded by the Austrian Federal Ministry of Sustainability and Tourism and the Federal States of Vorarlberg, Tyrol, Salzburg, Styria and Carinthia within the DaFNE project RGHeavyMetal (Nr. 101093). Digital elevation models were provided by the GIS Service of the Federal Governments of Vorarlberg, Tyrol, Salzburg, Styria and Carinthia. We acknowledge the very constructive suggestions and comments by Renato Colucci and Jörg Robl that greatly improved the paper.

\section{References}

Anderson, R.S., Anderson, L.S., Armstrong, W.H., Rossi, M.W., Crump, S.E., 2018. Glaciation if alpine valleys: The glacier- debris covered glacier - rock glacier continuum. Geomorphology, 311, 127-142. https://doi. org/10.1016/j.geomorph.2018.03.015.
Ballantyne, C.K., Kirkbridge, M.P., 1986. The characteristics and significance of some lateglacial protalus ramparts in upland Britain. Earth Surfaces Processes and Landforms, 11, 659-671. https://doi.org/10.1002/esp.32901110609

Bardinoni, F., Scotti, R., Sailer, R., Mair, V., 2019. Evaluating sources of uncertainty and variability in rock glacier inventories. Earth Surface Processes and Landforms, https://doi.org/10.1002/esp.4674

Barsch, D., 1996. Rockglaciers. Indicators for the present and former geoecology in high mountain environments. Springer, Berlin, 331 pp.

Beniston, M., 2005. Mountain climates and climatic change: An overview of processes focusing on the European Alps. Pure and Applied Geophysics, 162, 15871606. https://doi.org/10.1007/s00024-005-2684-9

Berthling, I., 2011. Beyond confusion: Rock glaciers as cryo-conditioned landforms. Geomorphology, 131, 98106. https://doi.org/10.1016/j.geomorph.2011.05.002

Boccali, C., Zebre, M., Colucci, R.R., 2019. Geometry and paleo-ice content of rock glsaciers in the southeastern Alps (NE Italy - NW Slovenia). Journal of Maps, 15/2, 346-355. https://doi.org/10.1080/17445647.2019.1595 753

Boeckli, L., Brenning, A., Gruber, S., Noetzli, J., 2012. Permafrost distribution in the European Alps: calculation and evaluation of an index map and summary statistics. Cryosphere, 6, 807-820. https://doi.org/10.5194/tc-6807-2012

Bollmann, E., Rieg, L., Spross, M., Sailer, R., Bucher, K., Maukisch, M., Monreal, M., Zischg, A., Mair, V., Lang, K., Stötter, J., 2012. Blockgletscherkatatser Südtirol - Erstellung und Analyse. In: Stötter, J, Sailer, R. (eds.), Permafrost in Südtirol. Innsbrucker Geographische Studien 39, pp. 147-171.

Colucci, R.R., Boccali, C., Žebre, M., Guglielmin, M., 2016. Rock glaciers, protalus ramparts and pronival ramparts in the south-eastern Alps. Geomorphology, 269, 112121. https://doi.org/10.1016/j.geomorph.2016.06.039

Colucci, R.R., Forte, E., Zebre, M., Maset, E., Zanettini, C., Guglielmin, M., 2019. Is that a relict rock glacier? Geomorphology, 330, 177-1898. https://doi.org/10.1016/j. geomorph.2019.02.002

Ehlers, J., Gibbard, P.L., Hughes, P.D., 2011. Quaternary Glaciations - Extent and Chronology. Developments in Quaternary Science, 15, Amsterdam. The Netherlands, 661-698. ISBN: 978-0-444-53447-7.

Fernandes, M., Palma, P., Lopes, L., Ruiz-Fernández, J., Pereira, P., Oliva, M., 2018. Spatial distribution and morphometry of permafrost-related landforms in the Central Pyrenees and associated paleoclimatic implications. Quaternary International, 470, 96-108. https://doi. org/10.1016/j.quaint.2017.08.071

Frauenfelder, R., Kääb, A., 2000. Towards a palaeoclimatic model of rock-glacier formation in the Swiss Alps. Annals of Glaciology, 31, 281-286. https://doi. org/10.3189/172756400781820264

Grassler, F., 1984. Alpenvereinseinteilung der Ostalpen (AVE). Berg'84 (Alpenvereinsjahrbuch 108), 215-224. 
Harrington, J.S., Mozil, A., Hayashi, M., Bentley, L.R., 2018. Groundwater flow and storage processes in an inactive rock glacier. Hydrological Processes, 32, 3070-3088. https://doi.org/10.1002/hyp.13248

Harrison, S., Whalley, B., Anderson, E., 2008. Relict rock glaciers and protalus lobes in the British Isles: implications for Late Pleistocene mountain geomorphology and palaeoclimate. Journal of Quaternary Science, 23/3, 287-304. https://doi.org/10.1002/jqs.1148

Haeberli, W., Schaub, Y., Huggel, C., 2017. Increasing risks related to landslides from degrading permafrost into new lakes in de-glaciating mountain ranges. Geomorphology, 293, 405-417. https://doi.org/10.1016/j.geomorph.2016.02.009

Hedding D.W., 2016. Pronival ramparts: A review. Progress in Physical Geography, 40/6, 835-855. https://doi. org/10.1177/0309133316678148

van Husen, D., 1996. Exkursionsführer zur Exkursion B1 der DEUQUA Tagung 1996, Gmunden Oberösterreich. Unpublished excursion guide of the German Quaternary Association (DEUQUA), Gmunden, Austria, 34 pp.

van Husen, D., 2011. Quaternary Glaciations in Austria. In: Ehlers, J., Gibbard, P.L., Hughes, P.D., 2011. Quaternary Glaciations - Extent and Chronology. Developments in Quaternary Science, 15, Amsterdam. The Netherlands, 661-698. ISBN: 978-0-444-53447-7.

Ikeda, A., Matsuoka, N., 2006. Pebbly versus bouldery rock glaciers: Morphology, structure and processes. Geomorphology, 73, 279-296. https://doi.org/10.1016/j.geomorph.2005.07.015

Ilyashuk, B.P., Ilyashuk, E.A., Psenner, R., Tessadri, R., Koinig, K.A., 2018. Rock glaciers in crystalline catchments: Hidden permafrost-related threats to alpine lakes. Global Change Biology, 24, 1548-1562. https://doi. org/10.1111/gcb.13985

Ivy-Ochs, S., Kober, F., 2008. Surface exposure dating with cosmogenic nuclides. Quaternary Science Journal, 57/1-2, 179-209.

Jarman, D., Wilson, P., Harrison, S., 2013. Are there any relict rock glaciers in the British mountains? Journal of Quaternary Science, 28/2, 131-143. https://doi. org/10.1002/jqs.2574

Jones, D.B., Harrison, S., Anderson, K., Selly, H.L., Wood, J.L., Betts, R.A., 2017. The distribution and hydrological significance of rock glaciers in the Nepalese Himalaya. Global and Planetary Change, 160,123-142. https://doi. org/10.1016/j.gloplacha.2017.11.005

Jones, D.B., Harrison, S., Anderson, K., Betts, R.A., 2018. Mountain rock glaciers contain globally significant water stores. Scientific Reports, 8, 2834. https://doi. org/10.1038/s41598-018-21244-W

Jones, D.B., Harrison, S., Anderson, K., Whalley, W.B., 2019. Rock glaciers and mountain hydrology: A review. Earth-Science Reviews, 193, 66-90. https://doi. org/10.1016/j.earscirev.2019.04.001

Kaufmann, V., Roth, K., Seier, G., 2017. Tschadinhorn Blockgletscher, Schobergruppe, Hohe Tauern - ein Beitrag zur aktuellen Kinematik. In: Lienhart, W. (Ed.):
Ingenieurvermessung '17. Beiträge zum 18. Internationalen Ingenieurvermessungskurs Graz, 2017, Wichmann Verlag, Berlin/Offenbach, p. 427-438.

Kellerer-Pirklbauer, A., 2008. The Schmidt-hammer as a relative age dating tool for rock glacier surfaces: examples from Northern and Central Europe. Proceedings of the Ninth International Conference on Permafrost (NICOP), University of Alaska, Fairbanks, USA, June 29 July 3, 2008, 913-918.

Kellerer-Pirklbauer, A., 2019. Long-term monitoring of sporadic permafrost at the eastern margin of the European Alps (Hochreichart, Seckauer Tauern range, Austria). Permafrost and Periglacial Processes, https:// doi.org/10.1002/ppp.2021

Kellerer-Pirklbauer, A., Lieb, G.K., Kleinferchner, H., 2012. A new rock glacier inventory of the Eastern European Alps. Austrian Journal of Earth Sciences, 105/2, 78-93.

Kellerer-Pirklbauer, A., Wagner, T., Winkler, G., 2016. Inventarisierung von blockgletscher-verdächtigen Formen und deren hydrologischen Einzugsgebieten in den steirischen Niederen Tauern mit Hilfe von hochaufgelösten Geländemodellen. Joannea Geologie und Palaeontologie, 12, 53-62.

Knight, J., Harrison, S., Jones, D.B., 2019. Rock glaciers and the geomorphological evolution of deglacierizing mountains. Geomorphology, 324, 14-24. https://doi. org/10.1016/j.geomorph.2018.09.020

Krainer, K., Mostler, W., 2002. Hydrology of active rock glaciers: examples from the Austrian Alps. Arctic Antarctic and Alpine Research, 34,142-149.

Krainer, K., Ribis, M., 2012. A rock glacier inventory of the Tyrolean Alps (Austria). Austrian Journal of Earth Sciences, 105/2, 32-47.

Krainer, K., Bressan, D., Dietre, B., Haas, J.N., Hajdas, I., Lang, K., Mair, V., Nickus, U., Reidl, D., Thies, H., Tonidandel, D., 2015. A 10,300-yearold permafrost core from the active rock glacier Lazaun, southern Ötztal Alps (South Tyrol, northern Italy). Quaternary Research, 83/2, 324335. https://doi.org/10.1016/j.yqres.2014.12.005

Lauber, U., Kotyla, P., Morche, D., Goldscheider, N., 2014. Hydrogeology of an Alpine rockfall aquifer system and its role in flood attenuation and maintaining baseflow. Hydrology and Earth System Sciences, 18, 4437-4452. https://dx.doi.org/10.5194/hess-18-4437-2014

Lieb, G.K., Kellerer-Pirklbauer, A., Kleinferchner, H., 2012. Second rock glacier inventory (RGI2) of Central and Eastern Austria, link to Shapefile. https://doi.pangaea. de/10.1594/PANGAEA.869805

Millar, C.I., Westfall, R.D., 2008. Rock glaciers and related periglacial landforms in the Sierra Nevada, CA, USA; inventory, distribution and climatic relationships. Quaternary International, 188, 90-104. https://dx.doi. org/10.1016/j.quaint.2007.06.004

Moran, A.P., Ivy-Ochs, S., Vockenhuber, C., Kerschner, H., 2016. Rock glacier development in the Northern Calcareous Alps at the Pleistocene-Holocene boundary. Geomorphology, 273, 178-188. https://dx.doi. org/10.1016/j.geomorph.2016.08.017 
Nagl, H., 1976. Die Raum-Zeit Verteilung der Blockgletscher in den Niederen Tauern und die eiszeitliche Vergletscherung der Seckauer Tauern. Mitteilungen des naturwissenschaftlichen Vereins für Steiermark, 106, 95-118.

NGP 2015 - 2. Nationaler Gewässerbewirtschaftungsplan (2015): BMLFUW, Sektion IV Wasserwirtschaft. https:// www.bmnt.gv.at/wasser/wisa/fachinformation/ngp/ ngp-2015.html

Onaca, A., Ardelean, F., Urdea, P., Magori, B., 2017. Southern Carpathian rock glaciers: Inventory, distribution and environmental controlling factors. Geomorphology, 293(Part B), 391-404. https://doi.org/10.1016/j.geomorph.2016.03.032

Palma, P., Oliva, M., García-Hernández, C., Gómez Ortiz, A., Ruiz-Fernández, J., Salvador-Franch, F.; Catarineu, M., 2017. Spatial characterization of glacial and periglacial landforms in the highlands of Sierra Nevada (Spain). Science of the Total Environment, 584-585(Supplement C), 1256-1267.

Pauritsch, M., Wagner, T., Winkler, G., Birk, S., 2017. Investigating groundwater flow components in an Alpine relict rock glacier (Austria) using a numerical model. Hydrogeology Journal, 25, 371-383. https:// doi.org/10.1007/ s10040-016-1484-x

Popescu, R., Onaca, A., Urdea, P., Vespremeanu-Stroe, A., 2017. Spatial Distribution and Main Characteristics of Alpine Permafrost from Southern Carpathians, Romania. In: Radoane, M., Vespremeanu-Stroe, A. (eds) Landform Dynamics and Evolution in Romania. Springer Geography. Springer, Cham

Ribis, M., (2017): Geologisch-hydrogeologische und hydrochemische Untersuchungen in Permafrostbereichen der Ötztaler Alpen (Tirol, Österreich). PhD thesis, Department of Geology, University of Innsbruck. 326 p..

Rode, M., Kellerer-Pirklbauer, A., 2012. Schmidt-hammer exposure-age dating (SHD) of rock glaciers in the Schöderkogel-Eisenhut area, Schladminger Tauern Range, Austria. The Holocene, 22/7, 761-771. https:// doi.org/10.1177/0959683611430410

Rogger, M., Chirico, G.B., Hausmann, H., Krainer, K., Brückl, E., Stadler, P., Blöschl, G., 2017. Impact of mountain permafrost on flow path and runoff response in a high alpine catchment. Water Resources Research, 53, 12881308. https://doi.org/10.1002/2016WR019341

Scapozza, C., 2015. Investigation on protalus ramparts in the Swiss Alps. Geographica Helvetica, 70, 135-139.

Schmid, M.-O., Baral, P., Gruber, S., Shahi, S., Shrestha, T., Stumm, D., Wester, P., 2015. Assessment of permafrost distribution maps in the Hindu Kush Himalayan region using rock glaciers mapped in Google Earth. The Cryosphere, 9, 2089-2099. https://doi.org/10.5194/tc-92089-2015

Schmid, S.M., Flügenschuh, B., Kissling, E., Schuster, R., 2004. Tectonic map and overall architecture of the Alpine orogen. Eclogae Geologicae Helvetiae, 97/1, 93117. https://doi.org/10.1007/s00015-004-1113-x

Scotti, R., Crosta, G.B., Villa, A., 2017. Destabilisation of Creeping Permafrost: The Plator Rock Glacier case study
(Central Italian Alps). Permafrost and Periglacial Processes, 28, 224-236. https://doi.org/10.1002/ppp.1917

Sorg, A., Kääb, A., Roesch, A., Bigler, C., Stoffel, M., 2015. Contrasting responses of Central Asian rock glacierst o global warming. Scientific Reports, 5, 8228. https://doi. org/10.1038/srep08228

Stocker, K., Krainer, K., 2011. Abschlussbericht Blockgletscherinventar Vorarlberg. Unpublished report, 6p.

Stocker, K., 2012a. Geologie und Blockgletscher der Madererspitze (Vorarlberg). Unpublished master thesis, Institut für Geologie und Paläontologie, University of Innsbruck. 134 p.

Stocker, K., 2012b. Blockgletscher in Vorarlberg und in der Verwallgruppe. Museumsverein Jahrbuch Vorarlberger Landesmuseum 2012, 124-139.

Thies, H., Nickus, U., Tessardi, R., Tropper, P., Krainer, K., 2017. Peculiar arsenic, copper, nickel, uranium, and yttrium-rich stone coatings in a high mountain stream in the Austrian Alps. Austrian Journal of Earth Sciences, 110/2. https://doi.org/10.17738/ajes.2017.0012

Untersweg, T., Schwendt, A., 1995. Die Quellen der Blockgletscher in den Niederen Tauern. Bericht der wasserwirtschaftlichen Planung Nr. 78, Graz, p. 76.

Untersweg, T., Schwendt, A., 1996. Blockgletscher und Quellen in den Niederen Tauern. Mitteilungen der Österreichischen Geologischen Gesellschaft, 87, 47-55.

Uxa, T., Mida, P., 2017. Rock glaciers in the Western and High Tatra Mountains, Western Carpathians. Journal of Maps, 13, 844-857. https://doi.org/10.1080/1744647.20 17.1378136

Wagner, T., Mayaud, C., Benischke, R., Birk, S., 2013. Ein besseres Verständnis des Lurbach-Karstsystems durch ein konzeptionelles Niederschlags-Abfluss-Modell. Grundwasser, 18, 225-235. https://doi.org/10.1007/ s00767-013-0234-4

Wagner, T., Pauritsch, M., Winkler, G., 2016. Impact of relict rock glaciers on spring and stream flow of alpine watersheds: Examples of the Niedere Tauern Range, Eastern Alps (Austria). Austrian Journal of Earth Sciences, 109/1, 84-98. https://doi.org/10.17738/ajes.2016.0006

Wagner, T., Winkler, G., Ribis, M., Kellerer-Pirklbauer, A., Lieb, G.K., Krainer, K., 2018. Rock glaciers - prominent landforms in (protected areas of) Austria. Conference Volume, 6th Symposium for Research in Protected Areas, 689-692. https://doi.org/10.1553/np_symposium 2017

Wagner, T., Kainz, S., Wedenig, M., Pleschberger, R., Krainer, K., Kellerer-Pirklbauer, A., Ribis, M., Hergarten, S., Winkler, G., 2019a. Wasserwirtschaftiche Aspekte von Blockgletschern in Kristallingebieten der Ostalpen - Speicherverhalten, Abflussdynamik und Hydrochemie mit Schwerpunkt Schwermetallbelastungen (RGHeavyMetal) - Endbericht. Final report, 158 p. https://www.bmnt. gv.at/wasser/wasserqualitaet/RG-HeavyMetal.html

Wagner, T., Pauritsch, M., Mayaud, C., Kellerer-Pirklbauer, A., Thalheim, F., Winkler, G., 2019b. Controlling factors of microclimate in blocky surface layers of two nearby relict rock glaciers (Niedere Tauern Range, Austria). Geografiska Annaler: Series A, Physical Geography, 
101/4, 310-333. https://doi.org/10.1080/04353676.201 9.1670950

Winkler, G., Wagner, T., Pauritsch, M., Birk, S., Kellerer-Pirklbauer, A., Benischke, R., Leis, A., Morawetz, R., Schreilechner, M.G., Hergarten S., 2016. Identification and assessment of groundwater flow and storage components of the relict Schöneben Rock Glacier, Niedere Tauern Range, Eastern Alps (Austria). Hydrogeology Journal, 24, 937-953. https://doi.org/10.1007/s10040-015-1348-9

Winkler, G., Wagner, T., Krainer, K., Ribis, M., Hergarten, S., 2018a. Hydrogeology of Rock Glaciers - Storage Capacity and Drainage Dynamics - an Overview. In: Sychev, V.G., Mueller, L., Novel methods and results of landscape research in Europe, Central Asia and Siberia, Vol II/71, 329334.
Winkler, G., Wagner, T., Ribis, M., Pauritsch, M., Krainer, K., 2018b. The impact of rock glaciers on the runoff of alpine catchments in protected areas of Austria. Conference Volume, 6th Symposium for Research in Protected Areas, 735-738. https://doi.org/10.1553/np_symposium2017

Zebre, M, Stepisnik, U., 2015. Glaciokarst landforms and processes of the southern Dinaric Alps. Earth Surface Processes and Landforms, 40, 1493-1505. https://doi. org/10.1002/esp.3731

Received: 18.12 .2019

Accepted: 26.3.2020

Editorial handling: Kurt Stüwe 